\title{
Chemical Paste Characterization of Late Middle Preclassic-Period Ceramics from Holtun, Guatemala and its Implications for Production and Exchange
}

\author{
Michael G. Callaghan, michael.callaghan@ucf.edu 1 \\ Daniel E. Pierce, dep4g2@mail.missouri.edu 2 \\ Brigitte Kovacevich, brigitte.kovacevich@ucf.edu 1 \\ Michael D. Glascock, GlascockM@missouri.edu 2 \\ 1 University of Central Florida \\ 2 Research Reactor Center, University of Missouri
}

Draft submitted to Journal of Archaeological Science Reports, do not cite without permission of the authors 


\begin{abstract}
This study uses type: variety-mode classification, digital stereomicroscopy, and Neutron Activation Analysis (NAA) to characterize the paste composition of Late Middle Preclassic-period pottery at the site of Holtun, Guatemala. The sample consists of 98 sherds including unslipped utilitarian ware, slipped serving ware, and Mars Orange fine paste serving ware. NAA reveals four paste composition groups that approximate types produced through type: variety-mode classification and paste groups recognized by digital stereomicroscopy. The analysis suggests a pattern of production in which unslipped utilitarian vessels, slipped serving vessels, and Mars Orange fine paste serving vessels were produced using different paste recipes. While unslipped utilitarian vessels and slipped serving vessels may have been produced and consumed locally, Mars Orange fine paste serving vessels were likely produced in or around Holtun but consumed more widely. Results of this research suggest the Late Middle Preclassic-period ceramic economy at Holtun was characterized by incipient specialized production, and exchange of at least one ceramic ware. These results advance our understanding of Late Middle Preclassic-period ceramic production and exchange at Holtun, and inform the study of the development of socio-political complexity in the Maya lowlands.
\end{abstract}




\section{Introduction}

The Middle Preclassic period (1000-300 BCE) witnessed the development of complex society in the Maya lowlands. Previous and more recent investigations have revealed the origins of monumental architecture, long distance exchange of jade and obsidian, social hierarchy, and organized ritual during the Middle Preclassic (Doyle 2012; Inomata et al. 2013; Hammond 1999; Rice 2015; Traxler and Sharer 2016). Despite this research, there are few studies that focus on Middle Preclassic-period ceramic economy, and no published studies on ceramic production using compositional data. This is unfortunate, as previous study in the Maya lowlands using multiple forms of paste composition analysis have allowed archaeologists working on ceramics from the Classic and Postclassic periods to reconstruct ceramic production and exchange systems, as well as infer networks of socio-political interaction (Bishop and Rands 1982; Cecil 2013; Foias and Bishop 1997; Halperin and Bishop 2016; Neff 1989; Reents-Budet at al. 1994; Reents-Budet et al. 2004; Ting et al. 2015).

In order to address this gap, the authors undertook a study to characterize the paste composition of Late Middle Preclassic-period pottery at Holtun, Guatemala using type: variety-mode classification, digital stereomicroscopy, and Neutron Activation Analysis (NAA). The sample consisted of 98 sherds of unslipped utilitarian ware, slipped serving ware, and Mars Orange fine paste serving ware. Digital stereomicroscope analysis and NAA revealed discrete paste composition groups that approximated types produced through type: variety-mode classification. These analyses indicated a pattern of production in which unslipped utilitarian vessels, slipped serving vessels, and Mars 
Orange fine paste serving vessels were produced using different paste recipes. While unslipped utilitarian vessels and slipped serving vessels may have been produced and consumed locally, Mars Orange fine paste serving vessels were likely produced in or around Holtun but consumed more widely. Results of this research suggest the Late Middle Preclassic-period ceramic economy at Holtun was characterized by incipient specialized production, and exchange of at least one ceramic ware. These results advance our understanding of Late Middle Preclassic-period ceramic production and exchange at Holtun, and inform the study of the development of socio-political complexity in the Maya lowlands.

\section{Archaeological Background}

Geographically, the Maya lowlands encompass the department of Peten Guatemala, Belize, eastern Mexico including parts of the states of Chiapas, Tabasco, Campeche, Quintana Roo, and Yucatan; and a portion of western Honduras (the state of Copan). Chronologically, the Middle Preclassic period spans approximately 700 years from 1000-300 BCE, with sites seeing occupation most frequently during the Late Middle Preclassic (600-300 BCE). It is during this time that multiple forms of settlements appear in the lowlands ranging from communities like Cuello (Hammond 1999), K'axob (McAnany and Lopez Varela 1999), and Chan (Robin 2013) in Belize, to larger centers

like Nakbe (Hansen 1998), Seibal (Inomata et al. 2013), Cival (Estrada-Belli 2006), and Tikal (Coe 1965) in Guatemala, as well as Cahal Pech in Belize (Awe et al. 1990). Archaeological investigation of architecture, burials, artifacts, and landscapes at these 
sites reveal incipient, and in some cases established, signs of socio-political complexity including two or three-tiered settlement patterns, monumental architecture, specialized production, long distance exchange of hard stone, and unequal access to material, social, and political resources (Doyle 2012; Estrada-Belli 2010; Hammond 1999; Hansen 2001; Inomata et al. 2015; Rice 2015; Traxler and Sharer 2016). While typological analysis of ceramics has aided archaeologists in establishing site-wide chronologies and inferring interaction during the Late Middle Preclassic period (Callaghan and Neivens de Estrada 2016; Culbert 1993; Forsyth 1989; Gifford 1976; Kosakowsky 1987; Sabloff 1975), to date there are no published data on compositional studies of lowland Maya Late Middle Preclassic-period ceramics that can tell us specifically about production and exchange. One of the goals of the Holtun Archaeological Project was to perform compositional analyses on a sample of Late Middle Preclassic-period ceramics to create a database for this kind of material, begin formulating a model of Late Middle Preclassic ceramic production and exchange, and relate ceramic production to the development of sociopolitical complexity at the site.

Holtun, Guatemala has been the focus of investigations since 2010 (Kovacevich et al. 2012). The archaeological site of Holtun is an intermediate sized civic-ceremonial center with documented occupation beginning in the Late Middle Preclassic through Terminal Classic periods (600 BCE - AD 900) (Fialko 1999, 2002, 2011; Kovacevich et al. 2012; Ponciano 1995). The site is situated approximately $35 \mathrm{~km}$ southwest of Tikal and $12.3 \mathrm{~km}$ to the south of Yaxha (Figure 1). The formal site consists of a monumental epicenter built atop a karstic hill positioned along a roughly northeast-southwest linear axis (Figure 2). The approximate area of the epicenter is $970 \times 815 \mathrm{~m}$. The epicenter 
consists of 12 main groups and 86 structures all showing evidence of stone construction (Guzmán 2015). Major monumental architecture includes a Middle Preclassic period EGroup, Late Preclassic Triadic Group, ballcourt, stone-enclosed causeway, and various patio groups of stone architecture. Due to the presence of Late Middle Preclassic-period architecture and occupation, Holtun has yielded a significant sample of well-stratified ceramic material dating to the Late Middle Preclassic period that can be used for compositional analysis.

\section{$3 \quad$ Materials and Methods}

\subsection{Archaeological Samples}

The materials for this study consisted of 98 samples of archaeological ceramics from eight contexts dating to the Late Middle Preclassic-period at Holtun, Guatemala (Table 1). Seven of the eight contexts consisted of sealed stratified deposits located beneath a Late Middle Preclassic-period plaza floor in Group F, Patio A (see Figure 2). These are sequential layers of fill identified as HTN 1-1-10 through HTN 1-1-16 (Kovacevich et al. 2012). Four radiocarbon dates associated with contexts HTN 1-1-12 through HTN 1-1-15 place these layers of deposition between 540 and 473 BCE (calibrated), which is within the established Late Middle Preclassic-period range of 600300 BCE (Callaghan and Kovacevich 2016). Samples from HTN 1-1-10 through HTN 11-16 were selected due to their preservation, the sealed and stratified nature of these deposits, and their proximity to the Middle Preclassic-period ceremonial E-Group. EGroups are the oldest known monumental architecture in the Maya lowlands and are 
made up of two structures enclosing a plaza - a western pyramid and eastern range structure (Hansen 1998; Ricketson et al. 1937). Earlier in Maya archaeology these groups were identified as celestial observatories, where observers standing on the western pyramid could view the sun rising over the corners and middle of the eastern range structure during the solstices and equinox (Aveni and Hartung 1989). More recently, these groups have been identified as centers for early community ritual, civic gathering, or even market exchange (Doyle 2012). It was hypothesized that if ceramics made with foreign paste recipes would be present at Holtun, they would most likely occur in the early ceremonial core of the Middle Preclassic period, which is the E-Group in Group F, Patio B. The eighth context (HTN 3-1-6) comes from a sealed stratified deposit beneath a Late Middle Preclassic-period plaster floor in Group F, Patio C (see Figure 2). While no carbon date is associated with this context, stratigraphy and type: variety-mode classification of ceramics in this context indicate HTN 3-1-6 is a sealed, unmixed, Late Middle Preclassic-period deposit. Samples from HTN 3-1-6 were selected due to their preservation, the sealed and stratified nature of this deposit, and the type: variety composition of the context.

A type: variety-mode classification was performed on all sherds within the eight contexts (see Callaghan and Neivens de Estrada 2016; Gifford 1976). Three wares are represented in the sample (Figures 3-5, see Callaghan et al. in press for all type: varieties). Flores Waxy Ware is the slipped serving ware tradition of red, black, and cream colors of the Joventud, Chunhinta, and Pital Groups respectively. Slipped ceramics within Flores Waxy Ware also included two dichrome types: namely, Muxanal Red-oncream and Tierra Mojada Resist. Forms of slipped ceramics included bowls and jars. 
Unslipped utilitarian ceramics belong to Uaxactun Unslipped Ware and are classified within the Jocote and Achiotes Groups. Sherds of Mars Orange Paste Ware were also included in the sample. Mars Orange Paste Ware is characterized by fine orange paste with few to no inclusions, or volcanic ash inclusions. This ware appears in bowls, dishes, and jars.

Ninety-eight rim sherds were selected from contexts HTN 1-1-10 through HTN 11-16, and HTN 3-1-6. Sherds were chosen based on preservation, and attributes indicative of their respective type: variety. At least a $20 \%$ sample of the type within each context was sought, with many samples comprising over $30 \%$ of their type: variety within each context. Thin sections were prepared and are currently being analyzed. However, before petrographic analysis was initiated, pastes were analyzed with a Dinolite AMZ750 digital stereomicroscope. In previous studies by Callaghan (2008; Callaghan et al. 2013), stereomicroscopy proved to be a quick and reliable technique to characterize paste composition in the field that closely approximated mineralogical analysis using petrography. While it is no substitute for petrography, digital stereomicroscopy can allow analysts to identify major inclusions in paste fabrics that can later compliment other compositional studies. The stereoscopic analysis revealed two groups based on primary paste-inclusions: these included a crystalline calcite group and a volcanic ash group (see Figures 3-5) (Table 1). The crystalline calcite group contains the Jocote, Achiotes, Joventud, Chunhinta, Pital and Tierra Mojada ceramic groups. The volcanic ash group is predominantly composed of the Savana ceramic group, but also contains samples from the Joventud, Chunhinta, and Pital ceramic groups. As a note, we prefer the term "ash" because the particles in no way resemble larger pieces of black volcanic "glass" or 
obsidian. They appear as tiny shards under the microscope. After classification and microscopic analysis, the samples were sent to the Archaeometry Laboratory at the University of Missouri Research Reactor (MURR) for NAA.

\subsection{NAA Sample Preparation and Interpretation of Chemical Data}

Sample preparation, irradiation, and gamma-ray spectroscopy followed procedures established by Glascock (Glascock 1992) and Neff (1992, 2000). The interpretation of compositional data obtained from the analysis of archaeological materials is discussed in detail elsewhere (e.g., Baxter and Buck 2000; Bieber et al. 1976; Bishop and Neff 1989; Glascock 1992; Harbottle 1976; Neff 2000) and will only be briefly summarized here. The approach used to interpret chemical data for pottery involves hierarchical cluster analysis (HCA) and principal component analysis (PCA) to establish initial groupings within the sample. After constructing base groups through HCA and PCA, bivariate plots were used to refine groups. Next, Mahalonobis distance based probabilities were calculated to assess likelihood of group membership. A canonical discriminant analysis (CDA) was then conducted using the previously identified groups. Finally, Euclidian Distance Searches (EDS) were conducted to identify the most chemically similar previously analyzed samples in MURR's Mesoamerican NAA database.

\section{Results}




\subsection{Source Assignments from NAA}

As an initial step toward interpreting the pottery sample, the dataset was considered in isolation. This allowed examination of the general structure of the chemical data and identification of important variables for group formation. The analyses at MURR produced elemental concentration values for 33 elements in most of the analyzed samples. Strontium (Sr) and Nickel (Ni) were removed from all statistical techniques due to the high number of missing values within the dataset. The principal component loadings are presented in Figure 6 through an R-Q mode biplot of the principal component analysis and in Table 2. On PC1 (representing over 66 percent of the total sample variation), all elements display positive loadings except $\mathrm{Ca}$ and $\mathrm{Mn}$. The first five principal components alone explain approximately 92.22 percent of the variability in the sample.

Visual inspection of principal component biplots resulted in clearly defined chemical groups, which were used to refine groupings from hierarchal cluster analysis. Based on this principle component analysis, it appears that Cesium $(\mathrm{Cs})$, Calcium $(\mathrm{Ca})$, Potassium (K), Rubidium ( $\mathrm{Rb}$ ), and Sodium $(\mathrm{Na})$ explain the greatest amount of chemical variation across the first 5 PC's (Figures 7-10).

Other elements have also been found to be useful in visualizing the sample into distinct groups. However, it is apparent that significant chemical overlap between specimens necessitates a confirmation of group membership through other means. Visual inspection alone does not appear sufficient for confident group identification. For this reason, Mahalanobis distance calculations were also used for final group assignment 
(Callaghan et al. in press). After defining chemical groups, a canonical discriminant analysis (CDA) was conducted to maximize the variation between groups. Some overlap occurs between the groups, however, this overlap is minimal and Mahalonobis distance calculations further substantiate group assignments (Callaghan et al. in press).

\subsection{Geographic Identification of Source Groups from NAA}

The sample was compared to all samples in MURR's database originating in Guatemala, Belize, El Salvador, Honduras, and the eastern half of Mexico. The current sample was compared to the archived samples to determine which are the most similar chemically. The Euclidian distance search found the ten closest samples of the MURR database $(n=12,005)$. Based on the "criterion of abundance" (Bishop et al. 1982), if the majority of the closest samples were collected from a single location, the specimen in question likely originates from this location as well. In aggregate, the sample appears to be largely local in origin. However, each group trends to certain geographical areas (see Table 1).

\subsection{Final Group Assessment}

Group $1(n=22)$ is a tightly homogenous group easily distinguishable from the other groups. Specimens in this group are comparatively high in Potassium $(\mathrm{K})$, Scandium (Sc), Rubidium (Rb), Cesium (Cs), and Iron (Fe), while being notably low in Calcium (Ca). Based on the Euclidian Distance Search, Group 1 did not match any other 
samples in the MURR database at the time. The most similar specimens in MURR's database are samples from various sites in Belize and some samples from sites in the southern Gulf area of San Lorenzo, Oaxaca. Given that this group is not similar to any local samples, indicates that the group is either non-local in origin or possibly a previously undefined local group. We explain in the next section why we think the Group 1 ceramics were produced in the northeast lowlands using clay from an as yet undefined source. Also of note, all Group 1 ceramics are of Mars Orange Paste Ware and nearly $91 \%$ (20 of 22) have volcanic ash temper.

Group $2(\mathrm{n}=12)$ is similar to Group 1 in being high in Lanthanum (La), Europium (Eu), Terbium (Tb), and Ytterbium (Yb), and similar to groups 3 and 4 in many other elements. However, it is distinct in Calcium (Ca), Scandium (Sc), and Antimony ( $\mathrm{Sb}$ ). Geographically, these specimens appear to be generally similar to samples derived near the Belize, Guatemala border at sites such as El Pilar, and Tipu, Belize. Some samples are found to be similar to samples from the area of Northeastern Belize as well. All specimens in Group 2 are Calcite tempered and are almost exclusively Jocote Orangebrown: Jocote Variety of the Achiote Unslipped Ware. Also, of the four identified groups, this is the only group in which the majority of the samples are jars rather than bowls $(75 \%$; 9 of 12$)$.

Group $3(n=26)$ is the least homogenous of the groups. Group three has notable overlap with Groups 2 and 4 in most elements. Though the specimens are more chemically diverse, the group structure is maintained through all analyses. But, there are some notable differences between groups. For example, in considering the elements of Iron (Fe), Thorium (Th), and Scandium (Sc), Group 3 occupies the space between the 
second and fourth group. Geographically, this group is most similar with specimens from northeast Belize although it shows some similarities with samples from the Lake Petén region as well. Ninety six percent of the specimens (25 of 26) are Flores Waxy Wares.

Group $4(n=30)$ is comparatively low in many elements including Potassium (K), Rubidium (Rb), Antimony (Sb), Iron (Fe), Cesium (Cs), Ytterbium (Yb), and Uranium (U), while being comparatively high in Calcium (Ca). Mostly, this group is chemically similar to specimens originating in Northwestern Belize, specifically the Three Rivers region. However, Peten Lake specimens are similar at times as well. Most of these specimens are Flores Waxy Wares (77\%), while this group is basically evenly split between bowls and jars. It should also be noted that the majority of the black-slipped ceramics are from this group $(77 \%)$ and nearly all are calcite tempered.

Finally, the unassigned specimens ( $n=9)$ were left unassigned due to either being significantly different from the four compositional groups or being chemically consistent with more than one group. In some occasions, specimens were left unassigned due to conflicting likelihoods based on the different analyses performed. Seven of nine of the unassigned specimens were calcite tempered and geographically, they have various likely origins.

\section{Discussion}

The questions addressed in this discussion are, 1) where were the samples in this study most likely produced? 2) Are compositional groups related to the variables of typevariety, group, ware, temper, form, and decoration? 3) What are the implications of these 
findings for Late Middle Preclassic-period ceramic economy and their relation to the development of socio-political complexity at Holtun?

\subsection{Origin of Paste Composition Groups}

In relation to the first question, samples in paste groups 2-4 matched samples in MURR's database that are geographically close to Holtun. From nearest to furthest similar samples come from areas designated as "Lake Peten Region", "Belize-Guatemala Border", and "Northwest Belize (3 Rivers region)". These samples were taken from sherds at Holtun within Flores Waxy Ware and Uaxactun Unslipped Ware. Both of these wares were assumed to consist of locally produced cooking, storage, or serving vessels, and it appears they may have been. However, sherds from Group 1 are dissimilar to other more local specimens. Matches in the MURR database return two locations, namely "Oaxaca/Southern Gulf" and "Various (Belize)" (Table 1). All Group 1 samples come from sherds of Mars Orange Paste Ware. The NAA suggests one of two possibilities, the first being that Group 1 ceramics originate from more distant locales such as Oaxaca and the Southern Gulf. However, because so many matches appear in Belize it is safer to assume Mars Orange Paste Ware was produced in the northeastern Maya lowlands and exchanged from there. Typological data from other sites have also shown that Mars Orange Paste Ware is found in greatest quantities at sites in the Belize River Valley (Gifford 1976; Kosakowsky 2012). At this time, there is no other evidence of contact with Mexican sites at Holtun during the Late Middle Preclassic period. In addition, while diverse, the MURR database is not as rich in lowland Maya Late Middle Preclassic 
samples as it is for other time periods like the Late and Postclassic. It is possible that archaeologists working with MURR simply have not yet sampled paste groups that were used to produce Mars Orange Paste Ware. Only more analysis of archaeological ceramics and raw clay samples will alleviate this problem. In the meantime, the conclusion we can draw is that paste recipes used to make unslipped utilitarian vessels and slipped serving vessels at Holtun were most likely local in origin. The paste recipe used to make Mars Orange Paste Ware is dissimilar to these other paste recipes and either originates from a distinct local source near Holtun, or it was produced farther from Holtun, but still in the northeast Maya lowlands.

\subsubsection{Chemical Paste Composition and Relationship to other Variables}

It is clear that there are correlations between chemical group composition and other variables. Below we offer results and initial discussion of Chi-square tests of association between paste group and the following variables: type: variety, ceramic group, ceramic ware, temper, vessel form, and decoration (Callaghan et al. in press). Many of the tests are problematic in that multiple cells in the expected frequency counts fall below 5 . In order to remedy this problem, we tested paste groups against decreasing frequencies of variable categories. This is another area in which we are aided by initial classification using type: variety-mode. For example, we began by testing the relationship between type: variety and paste group. Unfortunately, because of the high number of type: varieties and the low number of evenly distributed samples, this produced multiple expected frequency counts less than 5. As a note, we considered using a Fisher's test, but 
because multiple categories had values of zero, we had the same problem. The results of the first Chi-square test between type: variety and paste group, although significant with a Chi-square of $241.33(\mathrm{df}=60$, alpha $=.05$, critical value $=79.082)$, are not robust. The same can be noted for a test between paste group and ceramic group (the next highest level of type: variety classification). Although significant with a Chi-square value of $199.69(\mathrm{df}=28$, alpha $=.05$, critical value $=41.3372)$, there are too many expected values that fall below 5 .

However, these tests do suggest a preliminary correlation between type: variety and paste composition. Namely, the Group 1 recipe was found exclusively among Mars Orange Paste Ware types within the Savana Group. The overwhelming majority of Jocote Orange-brown types were produced with the Group 2 recipe. Red-slipped ceramics of the Joventud Group were more frequently produced using the Group 3 recipe. Black-slipped ceramics of the Chunhinta Group were more frequently produced using clay from Group 4, as is Achiotes Unslipped. Finally, Pital Cream ceramics and ceramics with slipdecoration including Tierra Mojada Resist and Muxanal Red-on-cream were produced with both Group 3 and Group 4 recipes, as well as the unassigned group recipe.

When we test ware we also see a relationship to paste group with a Chi-square value of $143.34(\mathrm{df}=8$, alpha $=.05$, critical value $=15.5073)$. However, here too there are many cells with an expected value that fall below 5 . But we can see that there is a relationship between Group 1 ceramics and Mars Orange Paste Ware, Group 2 and 4 ceramics with Uaxactun Unslipped Ware, and Group 3 and 4 ceramics with Flores Waxy Ware. 
It is not until we test the relationship between paste group and temper that we produce a more reasonable Chi-square value of $64.52(\mathrm{df}=4$, alpha $=.05$, critical value $=$ 9.4877). These tests suggest calcite temper is positively correlated with Group 2, 3 and 4 ceramics, while ash temper is correlated with Group 1 ceramics. It should be noted that aside from Group 1 ceramics of Mars Orange Paste Ware, ash temper is also associated with Group 3 ceramics within Flores Waxy Ware; type: varieties include Joventud Red: Joventud Variety, Guitara Incised: Guitara Variety, Chunhinta Black: Chunhinta Variety, Centenario Black: Centenario Variety, and Muxanal Red-on-cream: Variety Unspecified. This suggests ash was an available resource at Holtun and was used to mix with the Group 3 local recipe. Decoration and form were also tested against paste group and produced significant Chi-square values, but also had an overabundance of expected values less 5 (see Callaghan et al. 2017). All of these tests suggest potters were making choices in vessel production that related clay composition and other variables.

\subsubsection{Implications for Late Middle Preclassic-period Ceramic Production and Exchange}

At Holtun it appears that the majority of slipped and unslipped serving and utilitarian ware bowls and jars were produced using locally made recipes. Evidence of ceramic exchange may come in the form of Mars Orange Paste Ware. If the clay used to make Mars Orange Paste Ware is not immediately available around the site of Holtun (within $5 \mathrm{~km}$ ), that source is most likely still located relatively close to Holtun (within 20$30 \mathrm{~km}$ ), possibly to the north and east, as Mars Orange Paste Ware is found in greatest 
abundance in the Belize River Valley (Gifford 1976; Kosakowsky 2012). This finding hints at the emergent value of certain Late Middle Preclassic containers because they were traded serving vessels, possibly used in commensal activities associated with ritual in the nearby E-Group complex. However, the extent of Mars Orange Paste Ware exchange is still unknown, making us hesitant to label it "long-distance" exchange. Based on this study and previously frequencies of Mars Orange Paste Ware (Callaghan and Neivens de Estrada 2016; Gifford 1976; Kosakowsky 2012), it appears Mars Orange Paste Ware was produced in the northeast Maya lowlands and exchanged within that region. Only future compositional analyses will lead to more conclusive patterns. In addition to trade, typological data also indicate local potters were in contact with other lowland Maya Late Middle Preclassic-period sites. While the ceramic paste recipes may be local to Holtun, form, firing, finishing, and decoration techniques fit well within known Late Middle Preclassic-period conventions. Holtun potters learned or brought these technologies from somewhere and were not producing and trading their wares in isolation from other groups.

The data also suggest incipient specialization in ceramic production at Holtun. It appears that chemical paste composition is correlated with paste preparation, surface finishing, and decoration. Late Middle Preclassic-period Holtun potters were making conscious choices about what kinds of clays and inclusions should be combined to make specific vessel forms with specific slip colors, surface treatments, and decoration. While at this point we cannot speak to particular parameters of craft specialization (see Costin 1991), we can at least say that Late Middle Preclassic-period pottery production at Holtun involved an exclusive skillset that most likely not everyone in the early community 
mastered. Similarly, while we cannot say that the pottery exhibits evidence of standardization (see Rice 1981:286; 1987:201-204), the correlation between paste composition and other variables hint at the possibility that few people may have been involved in the production of specific types and wares, and that these few people were making the same choices over and over again. These potters could have been producing more pottery than needed for household consumption and this may indicate a very low level of specialization and even incipient standardization in the Late Middle Preclassic period, which can been argued as an indicator of social complexity (Blackman et al. 1993; Clark and Parry 1991; Costin and Hagstrum 1995; Rice et al. 1981). However, it is important to note that the relationship between the standardization of paste composition, number of producers ("scale" [Costin 1991]), and specialization is extremely complicated and depends on multiple social and ecological variables (Arnold 2000; Costin 2000). The current compositional dataset is by no means robust enough to conclude ceramic production was specialized, but the data do suggest a definite correlation between paste recipes and type: varieties.

\section{Conclusions}

This study is the first of its kind and has led to significant methodological and theoretical conclusions. Our research shows that type: variety-mode classification approximates paste groups created by digital stereomicroscopy and NAA. The study also shows that despite being a bulk technique, NAA has the ability to discriminate between multiple local sources of clay (possibly within $5 \mathrm{~km}$ ). Our research concludes ceramic 
production during the Late Middle Preclasic period at Holtun was local with one exclusive regional trade ware. The compositional and typological data also lead us to conclude that ceramic specialization was emerging during the Late Middle Preclassic period at Holtun in conjunction with other social institutions. While not every site may exhibit the same patterns that we found at Holtun, we have produced the first dataset that can be tested against data from other sites. We will continue to test this model with material from Holtun and look forward to comparing results with Late Middle Preclassicperiod compositional studies of ceramics from other lowland Maya sites.

\section{Acknowledgments}

This research was funded by a National Science Foundation senior project research grant (BCS-1430954) and National Science Foundation grant to the Archaeometry Laboratory at the University of Missouri Research Reactor (BCS1415403). We thank Karla J. Cardona Caravantes, Co-Director of the Holtun Archaeological Project, and the Instituto de Antropología e Historía (IDAEH) for facilitating export of the samples used in this study. We also thank Whitney Goodwin and Rodrigo Guzman for their work on sherd images and maps used in this article. We thank Shilo Bender and Aurora Blanchard for their role in preparing the samples for irradiation.

Finally, we thank two anonymous reviewers for their thoughtful and helpful suggestions. 


\section{Figure Captions}

Figure $1 \quad$ Map of Guatemala showing location of Holtun (Guzman 2016)

Figure 2 Map of Holtun epicenter showing Group F (Guzman 2016)

Figure 3 a, Uaxactun Unslipped Ware, Achiotes Unslipped: Achiotes Variety sherd sample HTN 48; b, crystalline calcite paste at 50x; c, crystalline calcite paste at 250x (Photos by Goodwin 2014)

Figure 4 a, Flores Waxy Ware, Deprecio Incised: Deprecio Variety sherd sample HTN 69; b, crystalline calcite paste at 50x; c, crystalline calcite paste at 250x (Photos by Goodwin 2014)

Figure 5 a, Mars Orange Paste Ware, Savana Orange: Mucnal Variety sherd sample HTN 32; b, fine volcanic ash paste at 50x; c, fine volcanic ash paste at 250x (Photos by Goodwin 2014) (Photos by Goodwin 2014)

Figure 6 R-Q Mode biplot of the sample on Principal Component 1 and Principal Component 2

Figure $7 \quad$ Bi-variate plot of the sample showing the chemical composition of sample on axes of $\mathrm{Na}$ and $\mathrm{Ca}$

Figure 8 Bi-variate plot of the sample showing the chemical composition of sample on axes of $\mathrm{Na}$ and $\mathrm{Th}$

Figure 9 Bi-variate plot of the sample showing the chemical composition of sample on axes of Th and $\mathrm{K}$

Figure 10 Bi-variate plot of the sample showing the chemical composition of sample on axes of $\mathrm{Rb}$ and $\mathrm{Ca}$

\section{Table Captions}

Table 1 List of samples with context numbers, wares, type: variety, temper, form, source group, final source assignment, and closest matches in MURR database

Table 2 Elemental Loadings for the pottery sample on Principal Component Axes 1 through $5^{*}$.

*Values in bold explain the greatest amount of variation within each component. Those in italics explain a significant portion of the variation, but less than those in bold. 


\section{References Cited}

Arnold, Dean E. 2000. Does the Standardization of Ceramic Pastes Really Mean Specialization? Journal of Archaeological Method and Theory 7(4):333-375.

Aveni, Anthony F., and Horst Hartung 1989. Uaxactun, Guatemala; Group E and Similar Assemblages: An Archaeoastronomical Reconsideration. In World Archaeoastronomy, edited by Anthony F. Aveni, pp, 441-461. Cambridge University Press, Cambridge.

Awe, Jaime, Cassandra Bill, Mark Campbell, and David Cheetham. 1990. Early Middle Formative Occupation in the Central Maya Lowlands: Recent Evidence from Cahal Pech, Belize. Papers from the Institute of Archaeology 1, pp. 1-5. University College, London.

Baxter, M.J. and C.E. Buck 2000. Data Handling and Statistical Analysis. In Modern Analytical Methods in Art and Archaeology, edited by E. Ciliberto and G. Spoto, pp. 681746. John Wiley and Sons, New York

Blackman, M. James, Gil J. Stein, and Pamela B. Vandiver. 1993. The standardization hypothesis and ceramic mass production: technological, compositional, and metric indexes of craft specialization at Tell Leilan, Syria. American Antiquity 58(1):60-80.

Bieber, Alan M. Jr., Dorothea W. Brooks, Garman Harbottle, and Edward V. Sayre 1976. Application of multivariate techniques to analytical data on Aegean ceramics. Archaeometry 18:59-74. 
Bishop, Ronald L. and Hector Neff 1989. Compositional data analysis in archaeology. In Archaeological Chemistry IV, edited by R. O. Allen, pp. 576-586. Advances in Chemistry Series 220, American Chemical Society, Washington, D.C.

Bishop, Ronald L., and Robert L. Rands. 1982. Maya fine paste ceramics: a compositional perspective. In Excavations at Seibal Memoirs. Vol. 2. No. 15. Edited by Jeremy Sabloff, pp. 283-314. Peabody Museum of Archaeology and Ethnology Harvard University, Cambridge, MA.

Bishop, Ronald L., Robert L. Rands, and George R. Holley 1982. Ceramic compositional analysis in archaeological perspective. In Advances in Archaeological Method and Theory, vol. 5, pp. 275-330. Academic Press, New York.

Callaghan, Michael 2008. Technologies of Power: Ritual Economy and Ceramic Production in the Terminal Preclassic Period Holmul Region, Guatemala. $\mathrm{PhD}$ dissertation. Vanderbilt University department of Anthropology.

Callaghan, Michael, Francisco Estrada-Belli, and Nina Neivens de Estrada. 2013. Technological Style and Terminal Preclassic Orange Ceramics in the Holmul Region, Guatemala. In Ancient Maya Pottery: Classification, Analysis, and Interpretation. Edited by James John Aimers, pp. 121-141. University of Florida Press, Gainesville. 
Callaghan, Michael, and Brigitte Kovacevich. 2016. Anexo A: Analisis de Carbon de HTN 1-1. In Proyecto Arqueologico Holtun: Informe No. 5, Temporada 2015. Edited by Karla J. Cardona Cervantes, Michael Callaghan, and Brigitte Kovacevich pp. 314-316. Proyecto Arqueologico Holtun, Guatemala City, Guatemala.

Callaghan, Michael, and Nina Neivens de Estrada 2016. The Ceramic Sequence of the Holmul Region, Guatemala. Anthropological Papers of the University of Arizona No. 77. University of Arizona Press, Tucson.

Callaghan, Michael, Daniel Pierce, Brigitte Kovacevich, and Michael D. Glascock In press Paste Compositional Data From Late Middle Preclassic-period Ceramics at the Maya Site of Holtun, Guatemala. Data in Brief.

Cecil, Leslie G. 2013. Slips, Styles, and Trading Patterns: A Postclassic Perspective from Central Peten, Guatemala. In Ancient Maya Pottery: Classification, Analysis, and Interpretation, edited by James John Aimers, pp. 185-202. University Press of Florida, Gainesville.

Clark,John E., and William J. Parry. 1990. Craft Specialization and Cultural Complexity."In Research in Economic Anthropology, edited by Barry L. Isaac, 12: 289346. JAI Press, Greenwich, CT. 
Coe, William 1965. Tikal, Guatemala, and Emergent Maya Civilization. Science, New Series 147(3664):1401-1419.

Costin, Cathy L. 2000. The use of Ethnoarchaeology for the Archaeological Study of Ceramic Production. Journal of Archaeological Method and Theory 7(4):377-403.

1991. Craft Specialization: Issues Defining, Documenting, and Explaining the Organization of Production. In Archaeological Method and Theory Vol. 3. Edited by Michael Schiffer, pp. 1-56. University of Arizona Press: Tucson.

Costin, Cathy and Melissa Hagstrum 1995. Standardization, Labor Investment, Skill and the Organization of Ceramic Production in Late Prehispanic Highland Peru. American Antiquity 60(4): 619-639.

Culbert, T. Patrick 1993. The Ceramics of Tikal: Vessels from the Burials, Caches and Problematical Deposits: Tikal Report 25A. Vol. 81. University of Pennsylvania Museum, Philadelphia.

Doyle, James A. 2012. Regroup On "E-Groups": Monumentality and Early Centers in the Middle Preclassic Maya Lowlands. Latin American Antiquity 23(4):355-379.

Estrada-Belli, Francisco 2006. Lightning Sky, Rain, and the Maize God. The Ideology of Preclassic Maya Rulers at Cival, Peten, Guatemala. Ancient Mesoamerica 17(1):57-78. 
2010. The First Maya Civilization: Ritual and Power before the Classic Period. Routledge, London.

Fialko, Vilma 1999. Sangre, Sudor, y Lagrimas: Investigaciones de Arqueologia Regionalm no. 10, Holtun, Ixtinto, y La Naya. Manuscript in archive at PRONATTRIANGULO, IDAEH, Guatemala City, Guatemala. 2002. Documentacion del Arte Escultorico y Pictorico de la Acropolis Triadica de Holtun, Peten. Manuscript in archive at DEMOPRE. IDAEH, PRONAT-TRIANGULO-DEMOPRE, Guatemala City, Guatemala.

2011. Asentamiento y fachadas escultóricas del sitio arqueológico Holtun, Petén, Guatemala. In XXIV Simposio de Investigaciones Arqueológicas en Guatemala, 2010, edited by B. Arroyo, L. Paiz, A. Linares, and A. Arroyave, pp. 466-490. Museo Nacional de Arqueología y Etnología, Guatemala City, Guatemala (digital version).

Foias, Antonia E., and Ronald L. Bishop. 1997. Changing ceramic production and exchange in the Petexbatun region, Guatemala: Reconsidering the Classic Maya collapse. Ancient Mesoamerica 8.02 (1997): 275-291.

Forsyth, Donald W. 1989. The Ceramics of El Mirador, Peten, Guatemala. Papers of the New World Archaeological Foundation No. 63. New World Archaeological Foundation, Brigham Young University, Provo, UT. 
Gifford, James C. 1976. Prehistoric Pottery Analysis and the Ceramics of Barton Ramie in the Belize Valley. Memoirs of the Peabody Museum of Archaeology and Ethnology Vol. 18. Harvard University, Cambridge, Massachusetts.

Glascock, Michael D. 1992. Characterization of archaeological ceramics at MURR by neutron activation analysis and multivariate statistics. In Chemical Characterization of Ceramic Pastes in Archaeology, edited by H. Neff, pp. 11-26. Prehistory Press, Madison, WI.

Guzmán, Melvin Rodrigo 2015. Mapa Arqueológico de Holtun. In Proyecto Arqueológico Holtun Informe: No. 5, Temporada 2015, edited by Karla J. Cardona, Michael G. Callaghan, and Brigitte Kovacevich, pp. 26-59. Proyecto Arqueológico Holtun. Guatemala City, Guatemala.

Halperin, Christina D., and Ronald Bishop 2016. Chemical analysis of Late Classic Maya polychrome pottery paints and pastes from Central Peten, Guatemala. Journal of Archaeological Science 69:118-129.

Hammond, Norman 1991. Hammond, Norman. Cuello: an early Maya community in Belize. Cambridge University Press, Cambridge.

1999. The Genesis of Hierarchy: Mortuary and Offertory Ritual in the Pre-Classic at Cuello, Belize. In Social Patterns in Pre-Classic Mesoamerica, edited by David C. Grove and Rosemary Joyce, pp. 49-66. Dumbarton Oaks, Washington, D.C. 
Hansen, Richard 1998. Continuity and Disjunction: The Preclassic Antecedents of Classic Maya Architecture. In Function and Meaning and in Classic Maya Architecture, edited by Stephen Houston, pp. 49-122. Dumbarton Oaks, Washington, DC.

2001. The first cities: The beginnings of urbanization and state formation in the Maya Lowlands. In Maya: divine kings of the rainforest, edited by Nikolai Grube, pp. 50-65. H.F. Ullman, Germany.

Harbottle, Garman 1976. Activation analysis in archaeology. Radiochemistry 3:33-72. The Chemical Society, London.

Inomata, Takeshi, Jessica MacLellan, Daniela Triadan, Jessica Munson, Melissa Burham, Kazuo Aoyama, Hiroo Nasu, Flory Pinzón, and Hitoshi Yonenobu. 2015. Development of sedentary communities in the Maya lowlands: Coexisting mobile groups and public ceremonies at Ceibal, Guatemala. Proceedings of the National Academy of Sciences 112(14):4268-4273.

Inomata, Takeshi, Daniela Triadan, Kazuo Aoyama, Victor Castillo, and Hitoshi Yonenobu 2013. Early Ceremonial Constructions at Ceibal, Guatemala, and the Origins of Lowland Maya Civilization. Science 340(6131): 467-471. 
Kosakowsky, Laura J. 1987. Preclassic Maya Pottery at Cuello, Belize. Anthropological Papers of the University of Arizona No. 47. University of Arizona Press, Tucson. 2012. Ceramics and Chronology at Chan. In Chan: Ancient Maya Farming Community, edited by Cynthia Robin, pp. 42-70. University Press of Florida, Gainesville.

Kovacevich, Brigitte, Michael G. Callaghan, Patricia Rivera Castillo, and Rodrigo Guzman 2012. Investigaciones Arqueológicas en "Cabeza de Piedra": Resultados de Dos Temporadas del Campo en el Sitio de Holtun, Guatemala. In $X X V$ Simposio de Investigaciónes Arqueológicas en Guatemala, Guatemala City, Guatemala, edited by Barbara Arroyo, Lorena Paiz Arragon, and Hector Mejia, pp. 237-252. Museo Nacional de Arqueologia y Etnologia, Guatemala City, Guatemala.

McAnany, Patricia, and Sandra L. Lopez Varela 1999. Re-Creating the Formative Maya Village of K'axob: Chronology, Ceramic Complexes, and Ancestors in Architectural Context. Ancient Mesoamerica 10:147-168.

Neff, Hector 1989. Analysis of Mesoamerican plumbate pottery surfaces by laser ablation-inductively coupled plasma-mass spectrometry (LA-ICP-MS). Journal of Archaeological Science 30:21-35.

1992. Introduction. In Chemical Characterization of Ceramic Pastes in Archaeology, edited by H. Neff, pp. 1-10. Prehistory Press, Madison, WI. 
2000. Neutron activation analysis for provenance determination in archaeology. In Modern Analytical Methods in Art and Archaeology, edited by E. Ciliberto and G. Spoto, pp. 81-134. John Wiley and Sons, Inc., New York.

Ponciano, Erick M. 1995. Recientes Descubrimientos en el Departamento de Petén: Sitio Arqueológico Holtun, Aldea La Máquina, Flores. In VIII Simposio de Investigaciones Arqueológicas en Guatemala 1994, edited by J.P. Laporte and H. Escobedo, pp.484-492. Museo Nacional de Arqueología y Etnología, Guatemala City, Guatemala.

Reents-Budet, Dorie, Ronald L. Bishop, and Barbara MacLeod. 1994. Painting styles, workshop locations and pottery production. In Painting the Maya Universe: Royal Ceramics of the Classic Period. Edited by Dorie Reents-Budet, pp. 164-233. Duke University Press, Durham, NC.

Reents-Budet, Dorie, Ellen E. Bell, Loa P. Traxler, and Ronald L. Bishop. 2004. Early Classic ceramic offerings at Copan: a comparison of the Hunal, Margarita, and SubJaguar tombs. In Understanding Early classic Copan, edited by Ellen Bell, Marcello Canuto, and Robert Sharer, pp. 159-190. University of Pennsylvania Press, Philadelphia.

Rice, Prudence M. 2015. Middle Preclassic Interregional Interaction and the Maya Lowlands. Journal of Archaeological Research 23(1):1-47. 1987. Pottery Analysis: A Sourcebook. University of Chicago Press, Chicago. 
Rice, Prudence M., William Y. Adams, Joseph W. Ball, Whitney M. Davis, Timothy Earle, Robert E. Fry, Ian Hodder, L. R. V. Joesink-Mandeville, Charles C. Kolb, Masae Nishimura, Yasushi Kojo, Miguel Rivera Dorado, Barbara L. Stark and Sander E. Van Der Leeuw 1981. Evolution of Specialized Pottery Production: A Trial Model. Current Anthropology 22(3):219-240.

Ricketson, Oliver Garrison, Edith Bayles Ricketson, and Mrs Edith Hill Bayles Ricketson 1937. Uaxactun, Guatemala: Group E--1926-1931. Vol. 477. Carnegie institution of Washington, Washington, D.C.

Robin, Cynthia 2013. Everyday Life Matters: Maya Farmers at Chan. University Press of Florida, Gainsville.

Traxler, Loa P., and Robert J. Sharer (editors) 2016. The Origins of Maya States. University of Pennsylvania Museum of Archaeology and Anthropology, Philadelphia.

Sabloff, Jeremy A. 1975. Ceramics. In Excavations at Seibal, Department of Peten, Guatemala. Memoirs of the Peabody Museum of Archaeology and Ethnology, Volume 13, No. 2. Harvard University, Cambridge.

Ting, Carmen, Marcos Martinón-Torres, Elizabeth Graham, and Christophe Helmke 2015. The production and exchange of moulded-carved ceramics and the "Maya Collapse”. Journal of Archaeological Science 62:15-26. 
Figure 1

\section{Figure 1}

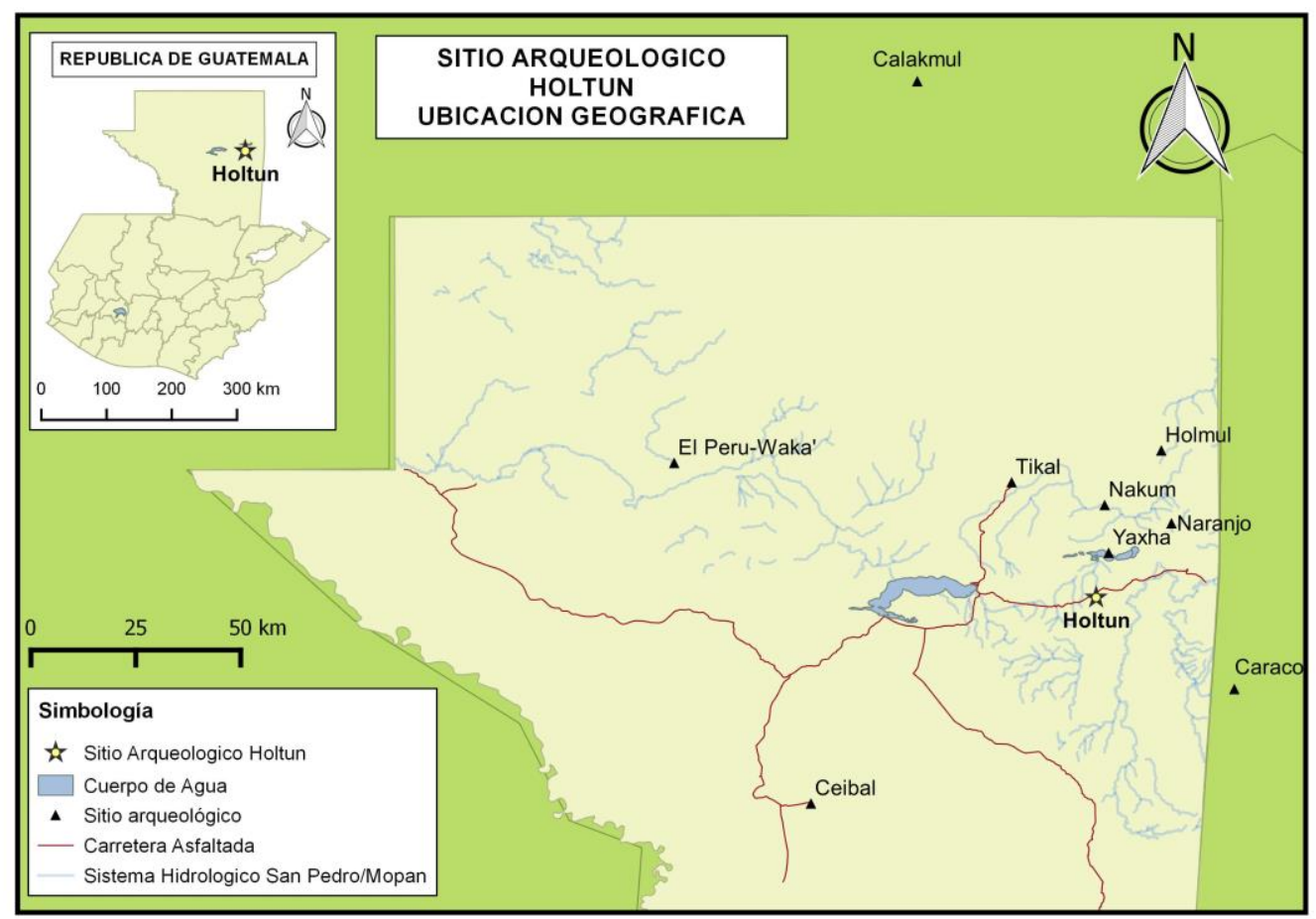




\section{Figure 2}

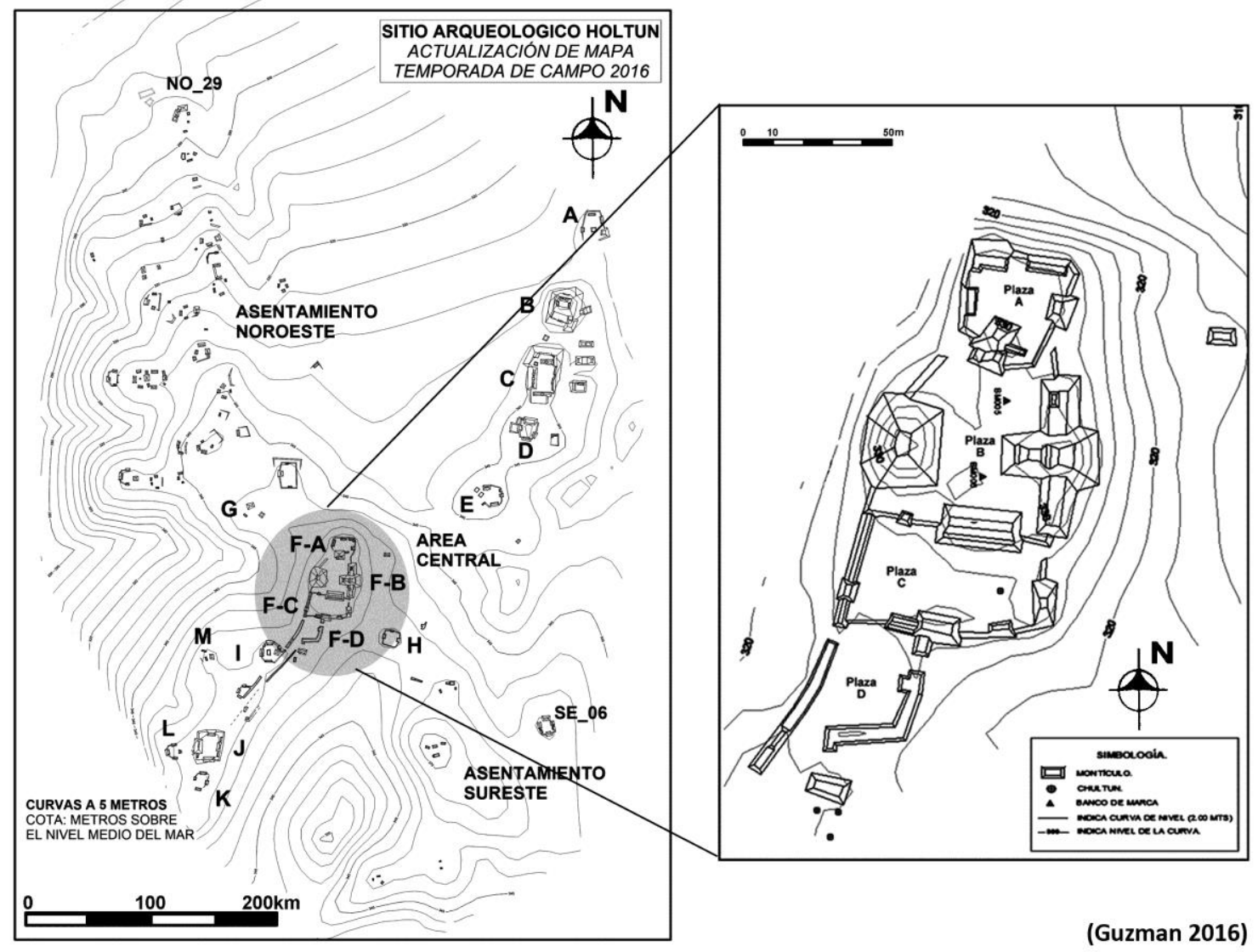


Figure 3
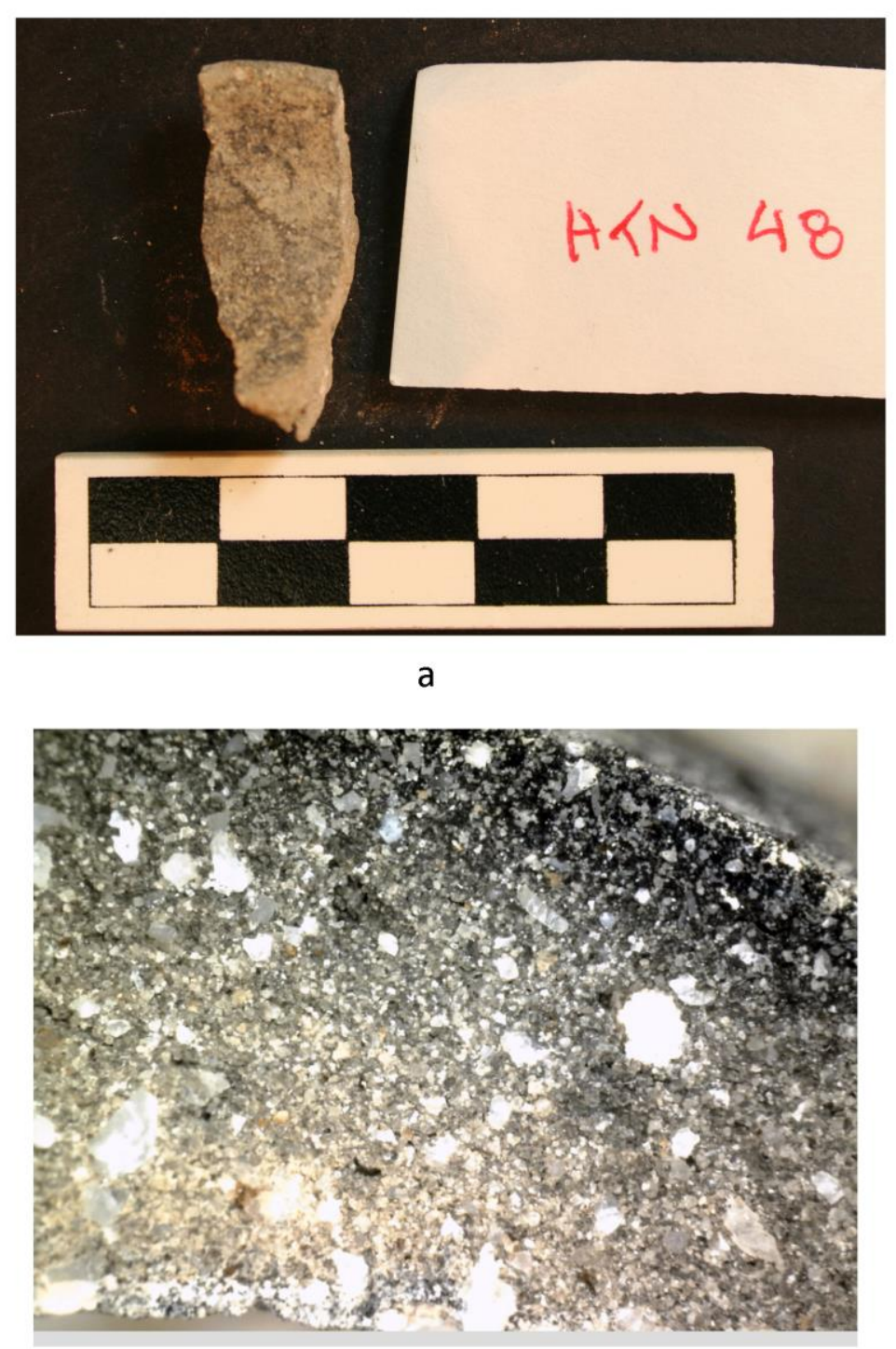

b

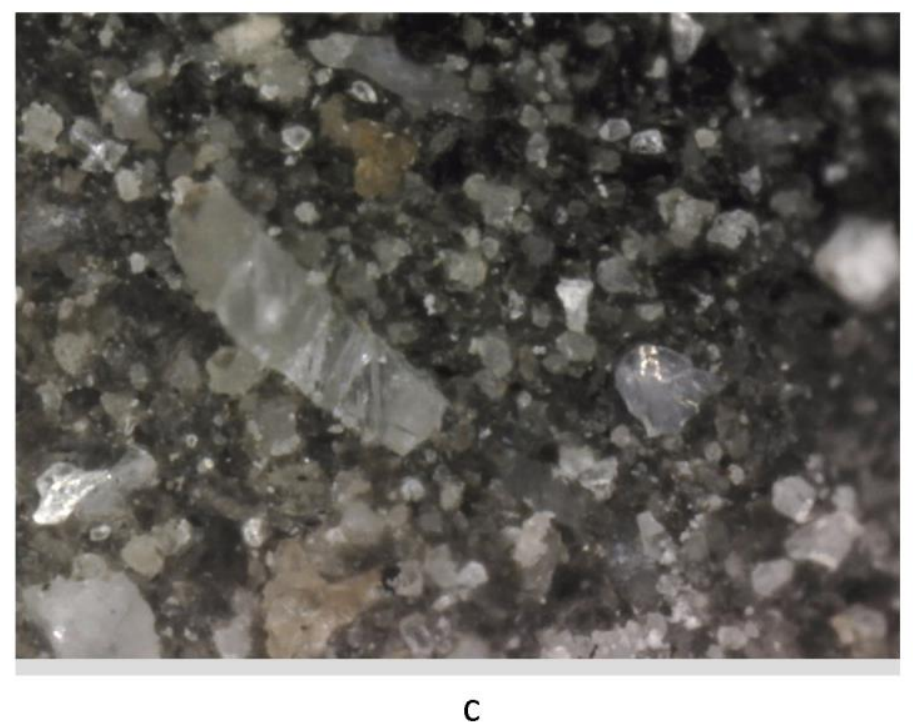


Figure 4
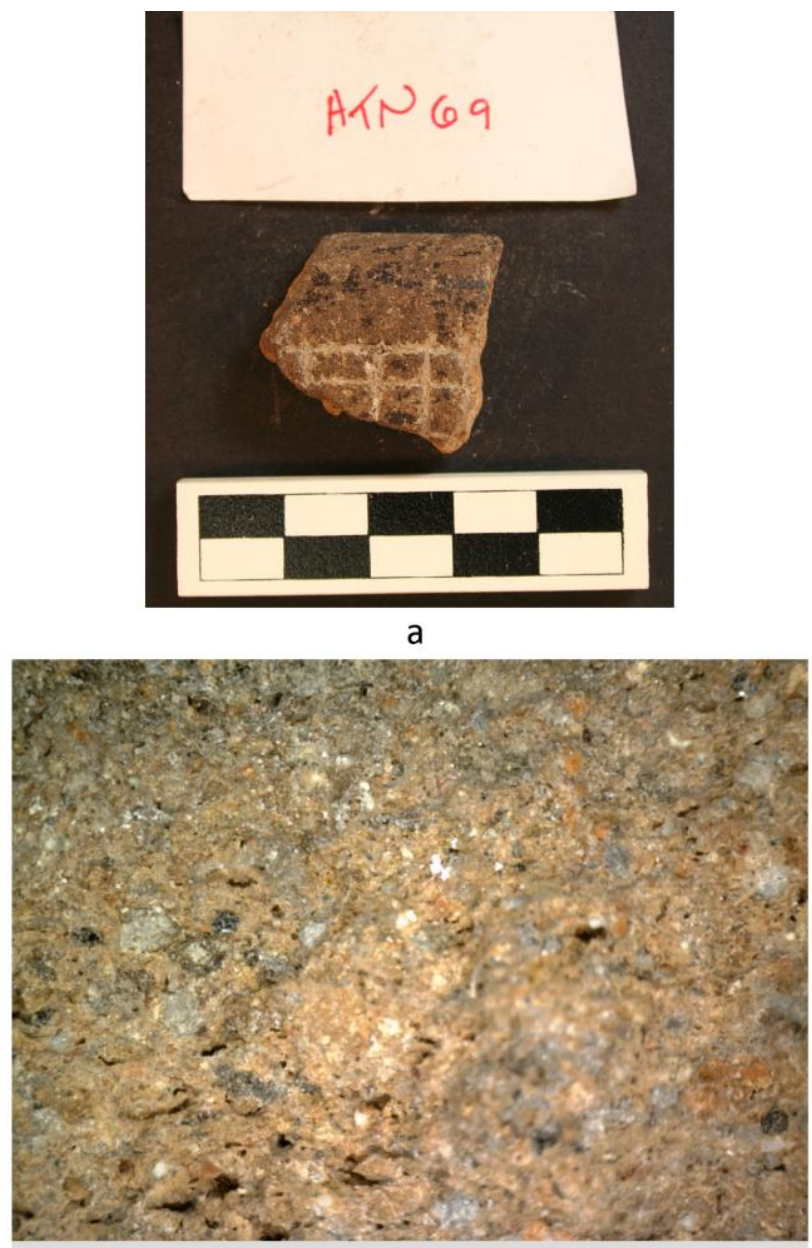

b

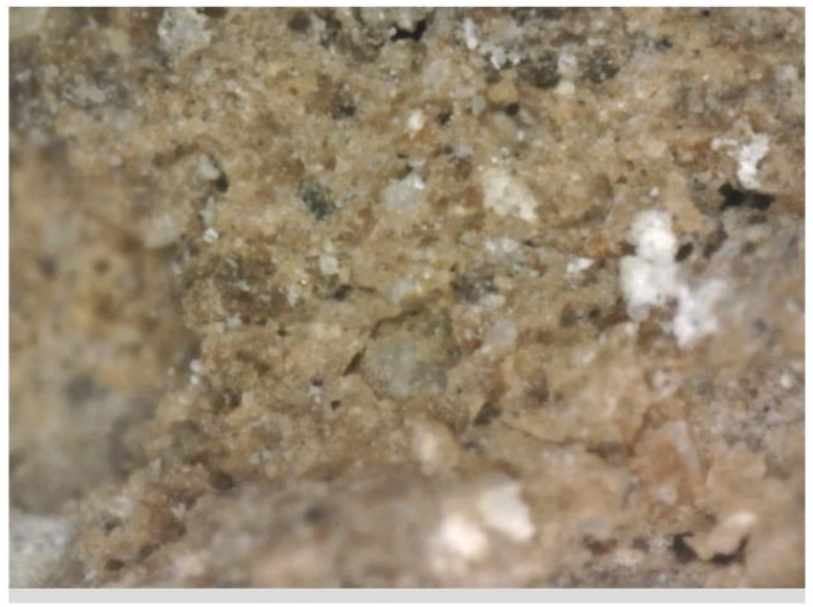

C 
Figure 5

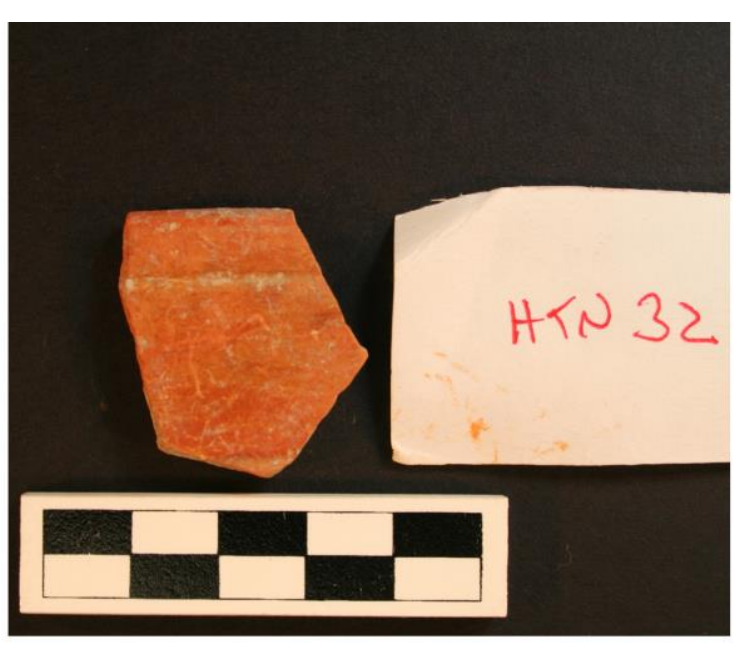

a

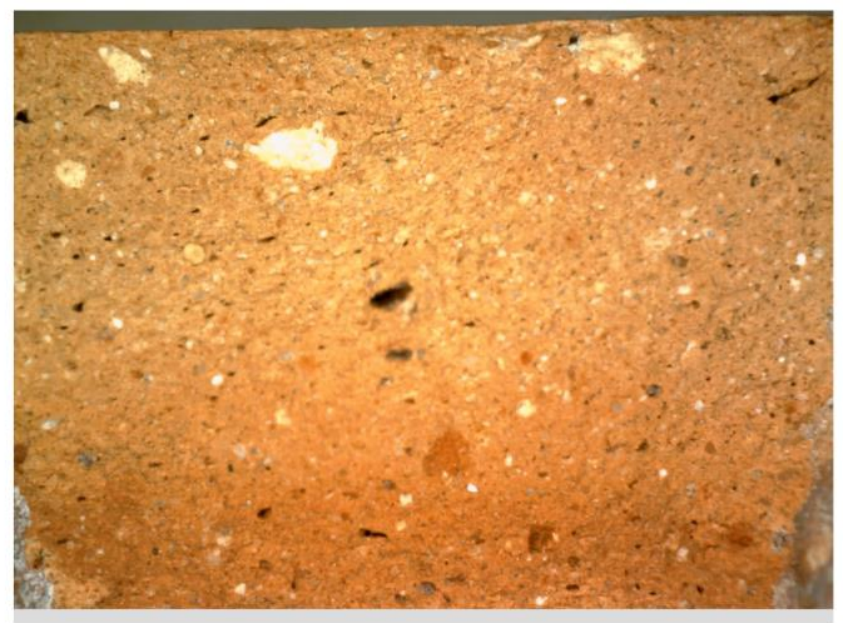

b

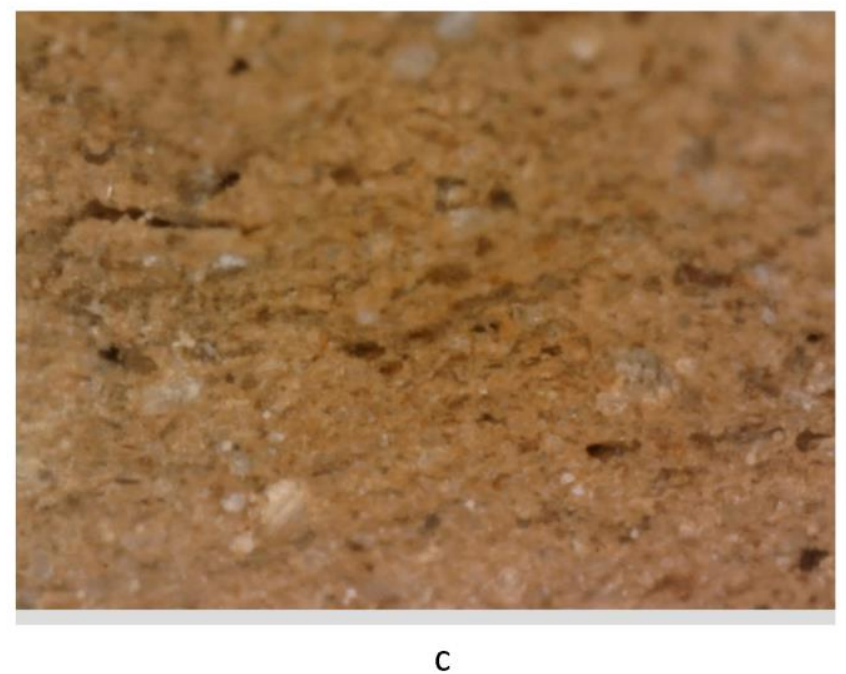




\section{Figure 6}

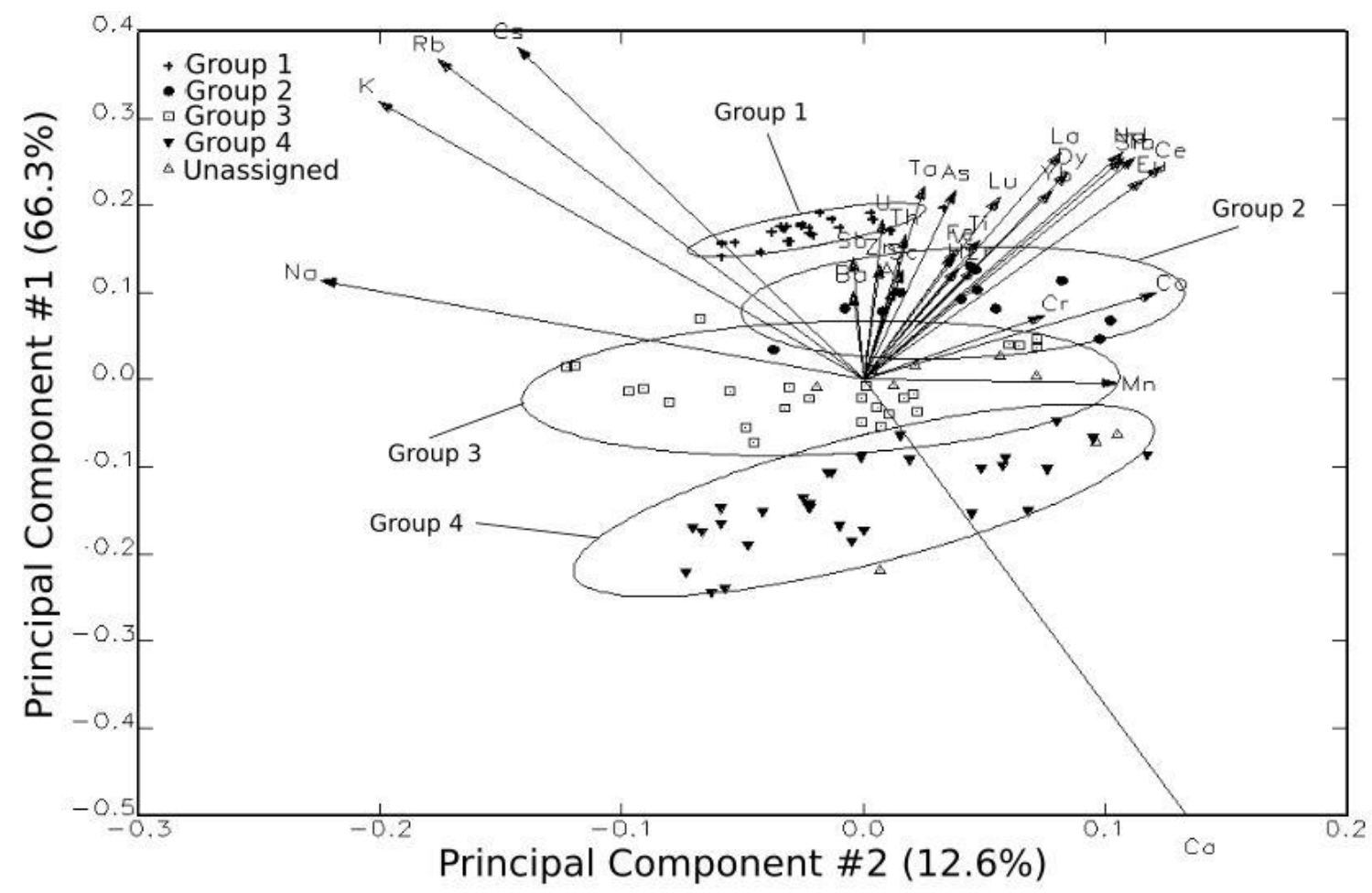


Figure 7

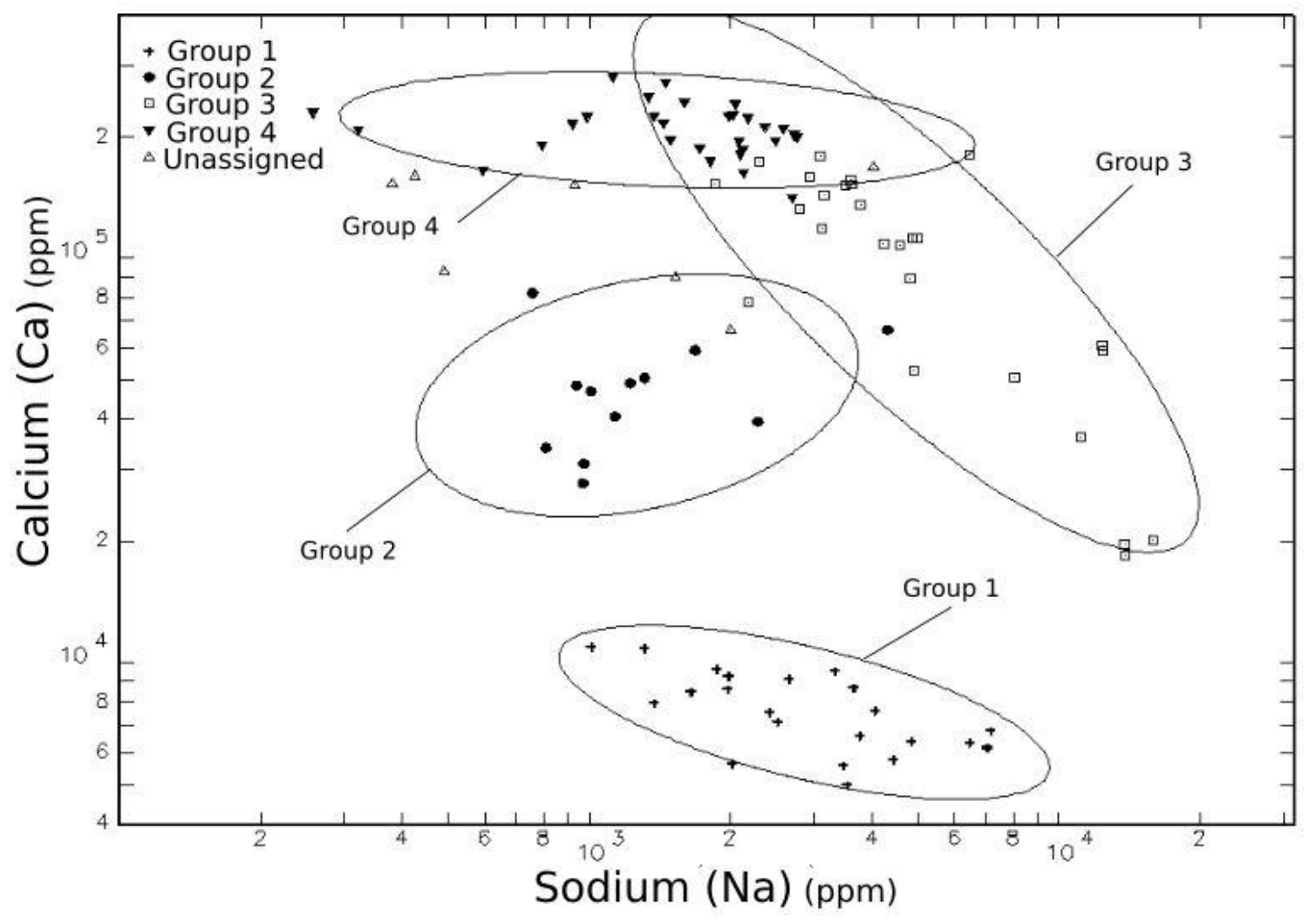


Figure 8

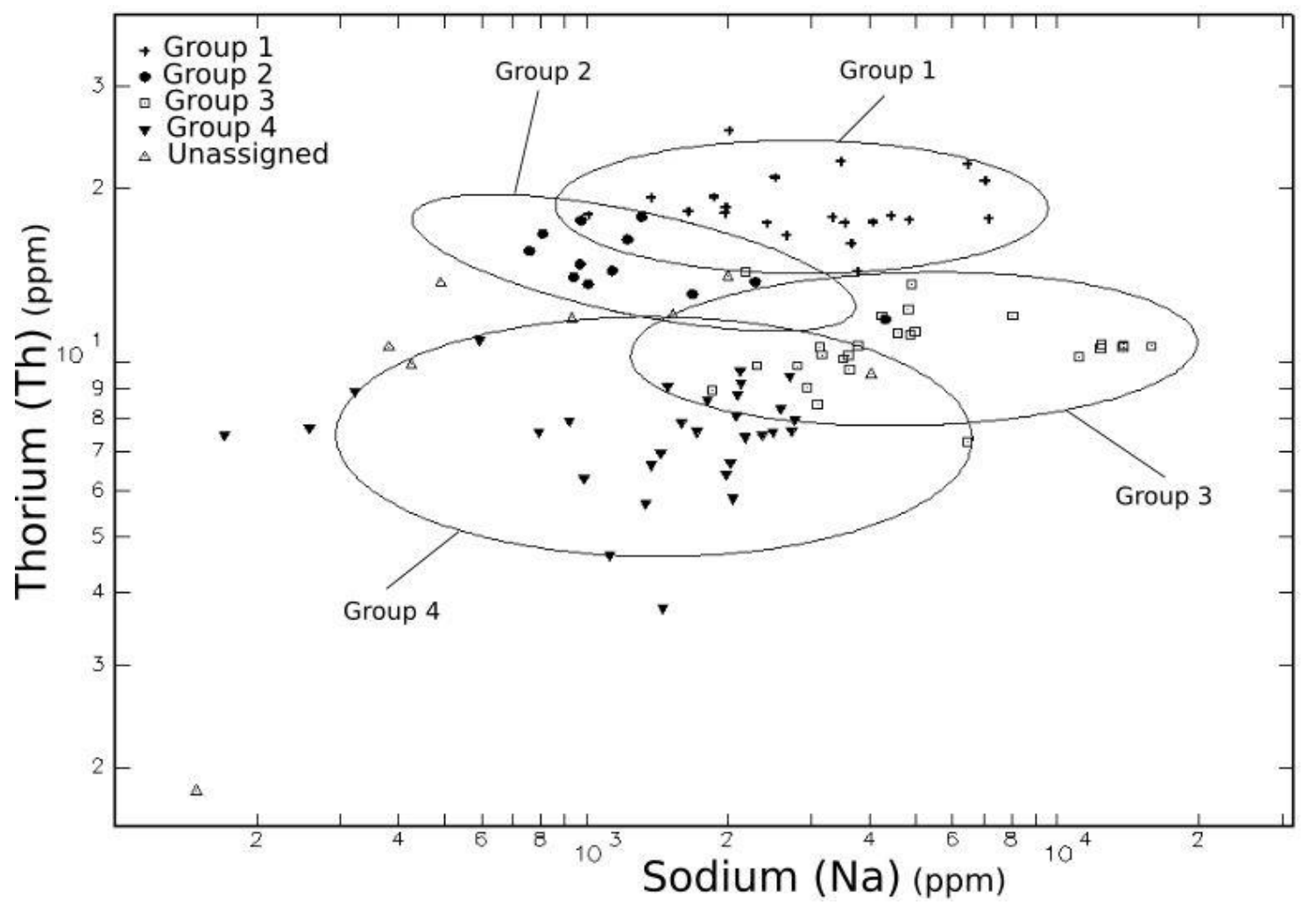


Figure 9

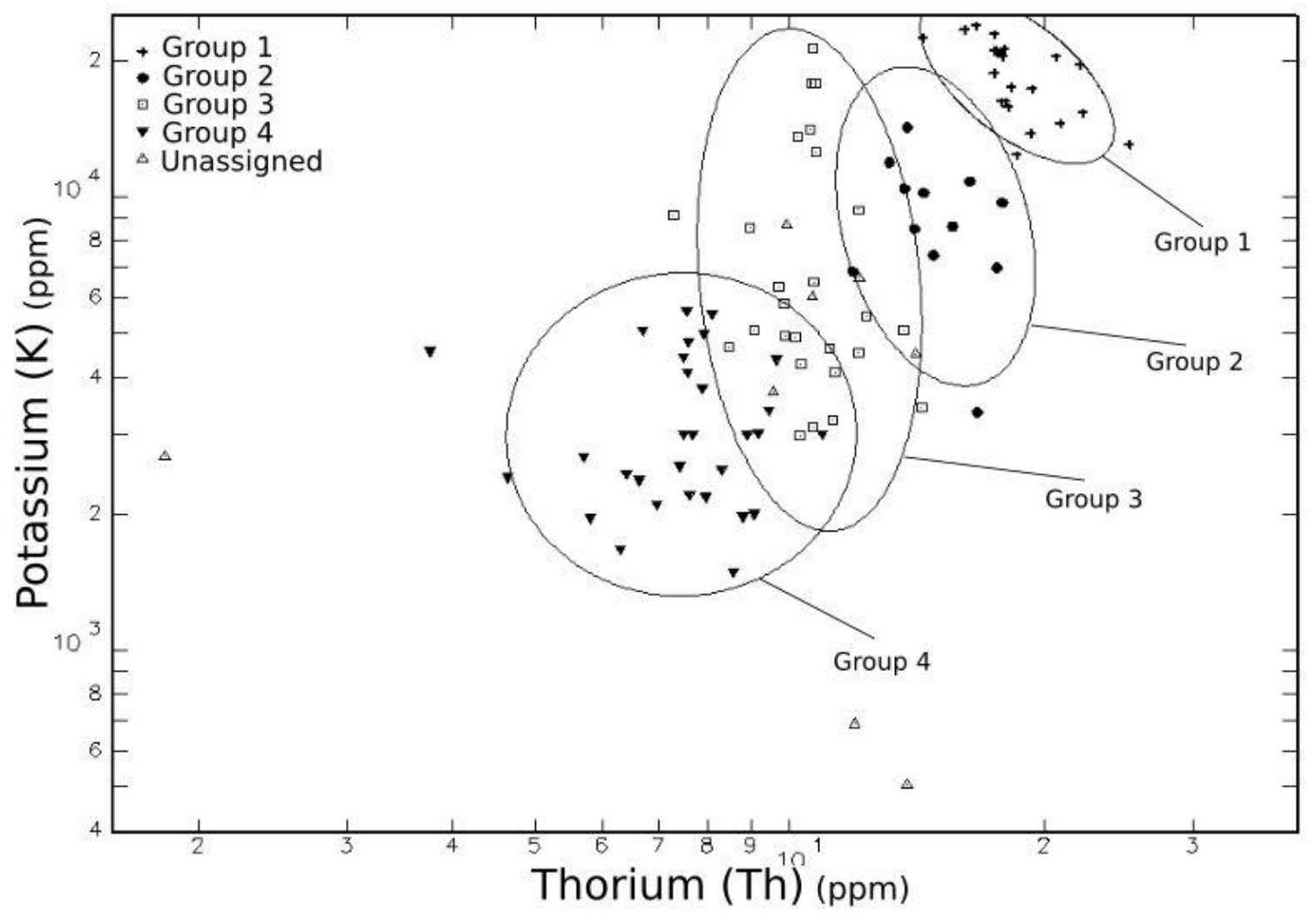


Figure 10

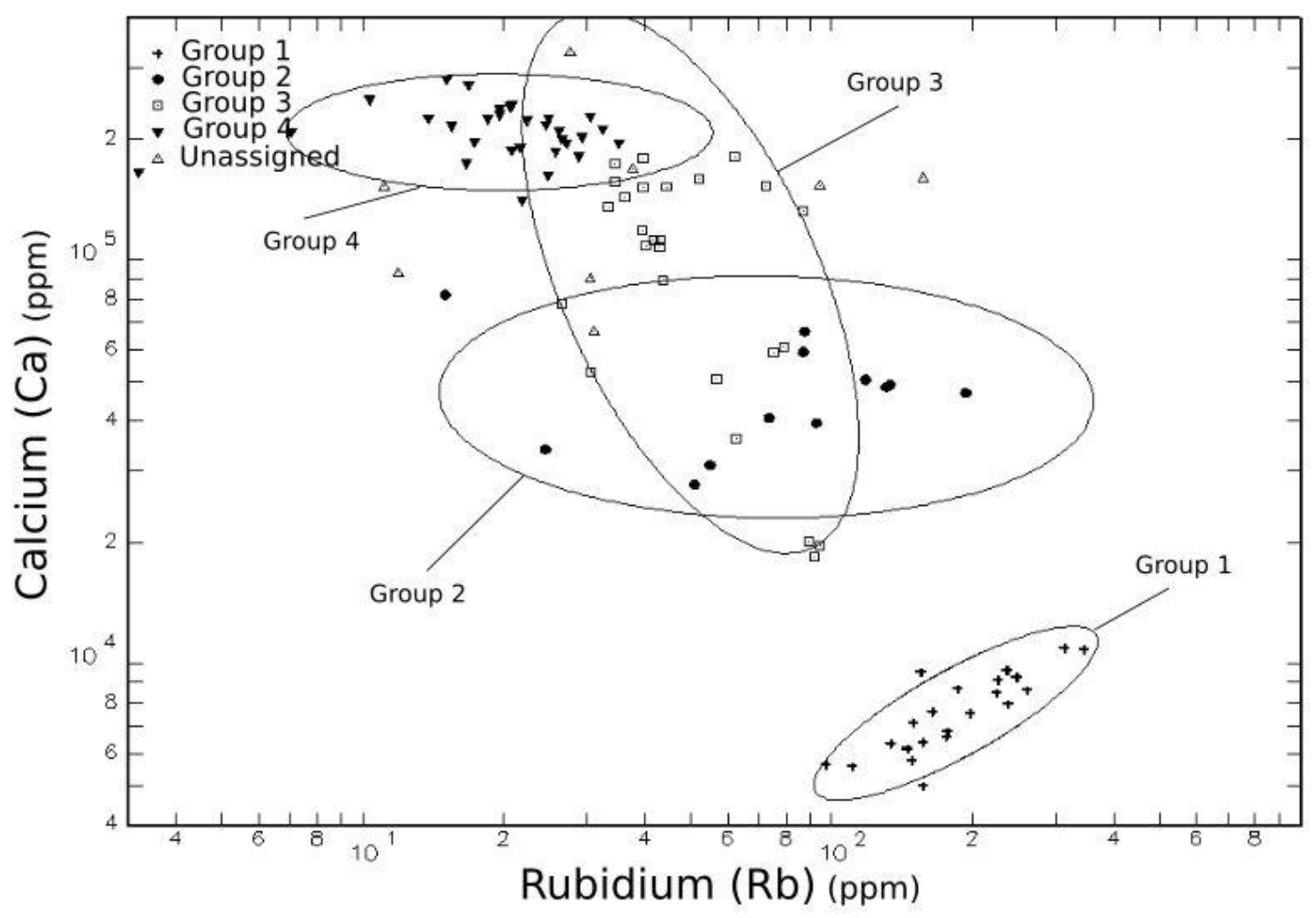


Table 1. List of samples with context numbers, wares, type: variety, temper, form, source group, final source assignment, and closest matches in MURR database

\begin{tabular}{|c|c|c|c|c|c|c|c|}
\hline ANID & Context & Vessel Ware & Type:Variety & Temper & Vessel Form & Source Group & Euclidian Distance to samples in MURR database \\
\hline HTNO01 & $1 / 1 / 10$ & Flores Waxy & Chunhinta Black: Chunhinta Variety & Calcite & jar & 4 & Lake Peten region \\
\hline HTNOO2 & $1 / 1 / 10$ & Flores Waxy & Deprecio Incised: Deprecio Variety & Calcite & jar & Unassigned & Lake Peten region \\
\hline HTNO03 & $1 / 1 / 10$ & Flores Waxy & Muxanal Red-on-cream: Muxanal Variety & Calcite & jar & Unassigned & Lake Peten region \\
\hline HTNOO4 & $1 / 1 / 10$ & Mars Orange & Reforma Incised: Mucnal Variety & Volcanic & bowl & 1 & Southern Gulf \\
\hline HTN005 & $1 / 1 / 10$ & Flores Waxy & Joventud Red: Joventud Variety & Calcite & bowl & 4 & Lake Peten region \\
\hline HTNO06 & $1 / 1 / 11$ & Flores Waxy & Deprecio Incised: Deprecio Variety & Calcite & bowl & 4 & Northwest Belize (3 Rivers region) \\
\hline HTN007 & $1 / 1 / 11$ & Flores Waxy & Chunhinta Black: Chunhinta Variety & Calcite & bowl & 4 & Northwest Belize (3 Rivers region) \\
\hline HTNO08 & $1 / 1 / 11$ & Flores Waxy & Joventud Red: Joventud Variety & Calcite & bowl & 3 & Lake Peten region \\
\hline HTN009 & $1 / 1 / 11$ & Flores Waxy & Joventud Red: Joventud Variety & Calcite & bowl & 4 & Lake Peten region \\
\hline HTN010 & $1 / 1 / 11$ & Flores Waxy & Tierra Mojada Resist: Tierra Mojada Variety & Calcite & bowl & 3 & Belize- Guatemala border \\
\hline HTN011 & $1 / 1 / 11$ & Achiotes Unslipped & Achiotes Unslipped: Achiotes Variety & Calcite & jar & 4 & Lake Peten region \\
\hline HTN012 & $1 / 1 / 12$ & Achiotes Unslipped & Achiotes Unslipped: Achiotes Variety & Calcite & jar & 4 & Lake Peten region/Belize- Guatemala border \\
\hline HTN013 & $1 / 1 / 12$ & Achiotes Unslipped & Achiotes Unslipped: Achiotes Variety & Calcite & jar & 4 & Various (Belize/ Yucatan) \\
\hline HTN014 & $1 / 1 / 12$ & Flores Waxy & Chunhinta Black: Chunhinta Variety & Calcite & jar & 3 & Lake Peten region \\
\hline HTN015 & $1 / 1 / 12$ & Flores Waxy & Joventud Red: Joventud Variety & Calcite & bowl & 4 & Northwest Belize (3 Rivers region) \\
\hline HTN016 & $1 / 1 / 12$ & Flores Waxy & Pital Cream: Pital Variety & Calcite & bowl & 3 & Northeast Belize \\
\hline HTN017 & $1 / 1 / 12$ & Flores Waxy & Guitara Incised: Guitara Variety & Calcite & bowl & 4 & Northwest Belize (3 Rivers region) \\
\hline HTN018 & $1 / 1 / 12$ & Flores Waxy & Centenario Fluted: Centenario Variety & Calcite & bowl & 3 & Lake Peten region \\
\hline HTN019 & $1 / 1 / 12$ & Flores Waxy & Tierra Mojada Resist: Tierra Mojada Variety & Calcite & bowl & 4 & Lake Peten region/ Northwest Belize (3 Rivers region) \\
\hline HTNO20 & $1 / 1 / 12$ & Mars Orange & Savana Orange: Rejolla Variety & Volcanic & bowl & 1 & Various \\
\hline HTNO21 & $1 / 1 / 12$ & Mars Orange & Savana Orange: Rejolla Variety & Volcanic & bowl & 1 & Various (Belize) \\
\hline HTN022 & $1 / 1 / 12$ & Mars Orange & Savana Orange: Savana Variety & Volcanic & bowl & 1 & Southern Gulf \\
\hline HTNO23 & $1 / 1 / 12$ & Flores Waxy & Chunhinta Black: Chunhinta Variety & Calcite & bowl & 4 & Lake Peten region/ Northwest Belize (3 Rivers region) \\
\hline HTNO24 & $1 / 1 / 12$ & Flores Waxy & Chunhinta Black: Chunhinta Variety & Calcite & jar & 4 & Lake Peten region \\
\hline HTNO25 & $1 / 1 / 12$ & Flores Waxy & Chunhinta Black: Chunhinta Variety & Volcanic & bowl & 3 & Lake Peten region/Belize- Guatemala border \\
\hline HTNO26 & $1 / 1 / 13$ & Flores Waxy & Joventud Red: Joventud Variety & Calcite & bowl & 3 & Northeast Belize \\
\hline
\end{tabular}




\begin{tabular}{|c|c|c|}
\hline HTN027 & $1 / 1 / 13$ & Flores Waxy \\
\hline HTN028 & $1 / 1 / 13$ & Flores Waxy \\
\hline HTN029 & $1 / 1 / 13$ & Flores Waxy \\
\hline HTNO3O & $1 / 1 / 13$ & Flores Waxy \\
\hline HTN031 & $1 / 1 / 13$ & Mars Orange \\
\hline HTN032 & $1 / 1 / 13$ & Mars Orange \\
\hline HTN033 & $1 / 1 / 13$ & Flores Waxy \\
\hline HTN034 & $1 / 1 / 13$ & Mars Orange \\
\hline HTN035 & $1 / 1 / 13$ & Mars Orange \\
\hline HTN036 & $1 / 1 / 14$ & Flores Waxy \\
\hline HTN037 & $1 / 1 / 14$ & Flores Waxy \\
\hline HTN038 & $1 / 1 / 14$ & Flores Waxy \\
\hline HTN039 & $1 / 1 / 14$ & Flores Waxy \\
\hline HTN040 & $1 / 1 / 14$ & Flores Waxy \\
\hline HTN041 & $1 / 1 / 14$ & Flores Waxy \\
\hline HTN042 & $1 / 1 / 14$ & Flores Waxy \\
\hline HTN043 & $1 / 1 / 14$ & Flores Waxy \\
\hline HTN044 & $1 / 1 / 14$ & Flores Waxy \\
\hline HTN045 & $1 / 1 / 14$ & Flores Waxy \\
\hline HTN046 & $1 / 1 / 15$ & Achiotes Unslipped \\
\hline HTN047 & $1 / 1 / 15$ & Achiotes Unslipped \\
\hline HTN048 & $1 / 1 / 15$ & Achiotes Unslipped \\
\hline HTN049 & $1 / 1 / 15$ & Unnamed \\
\hline HTN050 & $1 / 1 / 15$ & Flores Waxy \\
\hline HTN051 & $1 / 1 / 15$ & Flores Waxy \\
\hline HTN052 & $1 / 1 / 15$ & Flores Waxy \\
\hline HTN053 & $1 / 1 / 15$ & Flores Waxy \\
\hline HTN054 & $1 / 1 / 15$ & Flores Waxy \\
\hline
\end{tabular}

Guitara Incised: Guitara Variety
Joventud Red: Joventud Variety
Deprecio Incised: Deprecio Variety
Guitara Incised: Guitara Variety
Reforma Incised: Mucnal Variety
Reforma Incised: Mucnal Variety
Chunhinta Black: Chunhinta Variety
Savana Orange: Rejolla Variety
Savana Orange: Rejolla Variety
Joventud Red: Joventud Variety
Deprecio Incised: Deprecio Variety
Muxanal Red-on-cream: Muxanal Variety
Joventud Red: Joventud Variety
Joventud Red: Joventud Variety
Joventud Red: Joventud Variety
Paso Danto Incised: Paso Danto Variety
Chunhinta Black: Chunhinta Variety
Guitara Incised: Guitara Variety
Timax Incised: Timax Variety
Jocote Orange-brown: Jocote Variety
Jocote Orange-brown: Jocote Variety
Achiotes Unslipped: Achiotes Variety
Unnamed Eroded (Ah Pahm Complex?)
Paso Danto Incised: Paso Danto Variety
Guitara Incised: Guitara Variety
Deprecio Incised: Deprecio Variety
Guitara Incised: Guitara Variety
Timax Incised: Timax Variety
Jis

\begin{tabular}{lll} 
Volcanic & bowl & 3 \\
Volcanic & bowl & 3 \\
Calcite & bowl & 3 \\
Calcite & bowl & 2 \\
Volcanic & bowl & 1 \\
Volcanic & bowl & 1 \\
Calcite & jar & 4 \\
Volcanic & jar & 1 \\
Volcanic & jar & 1 \\
Calcite & bowl & 3 \\
Calcite & bowl & 4 \\
Calcite & bowl & Unassigned \\
Calcite & bowl & 3 \\
Calcite & bowl & 3 \\
Calcite & bowl & 3 \\
Calcite & bowl & 4 \\
Calcite & bowl & 4 \\
Calcite & jar & 4 \\
Calcite & bowl & 4 \\
Calcite & jar & 2 \\
Calcite & jar & 2 \\
Calcite & jar & 4 \\
Calcite & bowl & 3 \\
Calcite & bowl & 4 \\
Volcanic & bowl & 3 \\
Calcite & bowl & 3 \\
bolcanic & bowl & 3 \\
bowl & & 3 \\
\hline
\end{tabular}

Belize- Guatemala border

Belize- Guatemala border

Lake Peten region/ Northeast Belize

Northeast Belize/ Lake Peten region

Various

Various

Northwest Belize (3 Rivers region)

Various

Various

Northeast Belize

Northwest Belize (3 Rivers region)

Various

Northeast Belize

Northeast Belize

Lake Peten region

Northwest Belize (3 Rivers region)

Northwest Belize (3 Rivers region)

Lake Peten region

Northwest Belize (3 Rivers region)

Belize- Guatemala border

Belize- Guatemala border

Lake Peten region

Southern gulf

Northwest Belize (3 Rivers region)

Various

Lake Peten region

Belize- Guatemala border

Lake Peten region/ Northeast Belize 


\begin{tabular}{|c|c|c|c|c|c|c|c|}
\hline HTN055 & $1 / 1 / 15$ & Flores Waxy & Joventud Red: Joventud Variety & Calcite & bowl & 3 & Northeast Belize \\
\hline HTN056 & $1 / 1 / 15$ & Flores Waxy & Pital Cream: Pital Variety & Calcite & bowl & 3 & Lake Peten region/ Northeast Belize \\
\hline HTN057 & $1 / 1 / 15$ & Flores Waxy & Muxanal Red-on-cream: Variety Unspecified & Volcanic & bowl & 3 & Belize- Guatemala border \\
\hline HTN058 & $1 / 1 / 15$ & Mars Orange & Reforma Incised: Mucnal Variety & calcite & jar & 1 & Oaxaca/ Southern Gulf \\
\hline HTN059 & $1 / 1 / 15$ & Mars Orange & Savana Orange: Rejolla Variety & Volcanic & bowl & 1 & Various \\
\hline HTN060 & $1 / 1 / 15$ & Flores Waxy & Tierra Mojada Resist: Tierra Mojada Variety & Calcite & bowl & 4 & Northwest Belize (3 Rivers region) \\
\hline HTN061 & $1 / 1 / 15$ & Flores Waxy & Chunhinta Black: Chunhinta Variety & Calcite & bowl & 4 & Northwest Belize (3 Rivers region) \\
\hline HTN062 & $1 / 1 / 15$ & Flores Waxy & Joventud Red: Joventud Variety & Calcite & bowl & 3 & Various \\
\hline HTN063 & $1 / 1 / 15$ & Flores Waxy & Joventud Red: Joventud Variety & Calcite & bowl & 3 & Northeast Belize \\
\hline HTN064 & $1 / 1 / 16$ & Flores Waxy & Guitara Incised: Guitara Variety & Calcite & bowl & 4 & Various \\
\hline HTN065 & $1 / 1 / 16$ & Flores Waxy & Chunhinta Black: Chunhinta Variety & Calcite & jar & 4 & Northwest Belize (3 Rivers region) \\
\hline HTN066 & $1 / 1 / 16$ & Flores Waxy & Joventud Red: Joventud Variety & Calcite & bowl & 4 & Various (Belize) \\
\hline HTN067 & $3 / 1 / 06$ & Flores Waxy & Centenario Fluted: Centenario Variety & Volcanic & bowl & 3 & Northeast Belize \\
\hline HTN068 & $3 / 1 / 06$ & Flores Waxy & Tierra Mojada Resist: Tierra Mojada Variety & Calcite & bowl & Unassigned & Various \\
\hline HTN069 & $3 / 1 / 06$ & Flores Waxy & Deprecio Incised: Deprecio Variety & Calcite & bowl & Unassigned & Lake Peten region \\
\hline HTN070 & $3 / 1 / 06$ & Flores Waxy & Joventud Red: Joventud Variety & Calcite & bowl & 3 & Lake Peten region \\
\hline HTN071 & $3 / 1 / 06$ & Flores Waxy & Chunhinta Black: Chunhinta Variety & Calcite & bowl & 4 & Various \\
\hline HTN072 & $3 / 1 / 06$ & Achiotes Unslipped & Jocote Orange-brown: Jocote Variety & Calcite & jar & 2 & Belize- Guatemala border \\
\hline HTN073 & $3 / 1 / 06$ & Achiotes Unslipped & Jocote Orange-brown: Jocote Variety & Calcite & jar & 2 & Belize- Guatemala border \\
\hline HTN074 & $3 / 1 / 06$ & Achiotes Unslipped & Jocote Orange-brown: Jocote Variety & Calcite & jar & 2 & Belize- Guatemala border \\
\hline HTN075 & $3 / 1 / 06$ & Achiotes Unslipped & Jocote Orange-brown: Jocote Variety & Calcite & jar & 2 & Belize- Guatemala border \\
\hline HTN076 & $3 / 1 / 06$ & Achiotes Unslipped & Jocote Orange-brown: Jocote Variety & Calcite & jar & 2 & Northeast Belize \\
\hline HTN077 & $3 / 1 / 06$ & Achiotes Unslipped & Jocote Orange-brown: Jocote Variety & Calcite & jar & 2 & Northeast Belize \\
\hline HTN078 & $3 / 1 / 06$ & Achiotes Unslipped & Jocote Orange-brown: Jocote Variety & Calcite & jar & 2 & Northeast Belize \\
\hline HTN079 & $3 / 1 / 06$ & Achiotes Unslipped & Jocote Orange-brown: Jocote Variety & Calcite & jar & 2 & Belize- Guatemala border \\
\hline HTN080 & $3 / 1 / 06$ & Achiotes Unslipped & Jocote Orange-brown: Jocote Variety & Calcite & jar & 4 & Northwest Belize (3 Rivers region) \\
\hline HTN081 & $3 / 1 / 06$ & Achiotes Unslipped & Jocote Orange-brown: Jocote Variety & Calcite & jar & 2 & Lake Peten region \\
\hline HTN082g & $3 / 1 / 06$ & Mars Orange & Unnamed & indeterminate & indeterminate & Unassigned & Lake Peten region \\
\hline
\end{tabular}




\begin{tabular}{|c|c|c|c|c|c|c|c|}
\hline HTN082r & $3 / 1 / 06$ & Mars Orange & Unnamed & indeterminate & indeterminate & Unassigned & Belize- Guatemala border \\
\hline HTN083 & $3 / 1 / 06$ & Mars Orange & Savana Orange: Savana Variety & Volcanic & bowl & 1 & Southern Gulf \\
\hline HTN084 & $3 / 1 / 06$ & Mars Orange & Savana Orange: Rejolla Variety & Volcanic & bowl & 1 & Various (Belize) \\
\hline HTN085 & $3 / 1 / 06$ & Mars Orange & Savana Orange: Rejolla Variety & Calcite & jar & Unassigned & Belize- Guatemala border \\
\hline HTN086 & $3 / 1 / 06$ & Mars Orange & Savana Orange: Rejolla Variety & Volcanic & jar & 1 & Various (Belize) \\
\hline HTN087 & $3 / 1 / 06$ & Mars Orange & Savana Orange: Rejolla Variety & Volcanic & bowl & 1 & Various (Belize) \\
\hline HTN088 & $3 / 1 / 06$ & Mars Orange & Savana Orange: Rejolla Variety & Volcanic & bowl & 1 & Various (Belize) \\
\hline HTN089 & $3 / 1 / 06$ & Mars Orange & Savana Orange: Rejolla Variety & Volcanic & bowl & 1 & Various (Belize) \\
\hline HTN090 & $3 / 1 / 06$ & Mars Orange & Reforma Incised: Mucnal Variety & Volcanic & bowl & 1 & Various (Belize) \\
\hline HTN091 & $3 / 1 / 06$ & Mars Orange & Reforma Incised: Mucnal Variety & Volcanic & bowl & 1 & Various (Belize) \\
\hline HTN092 & $3 / 1 / 06$ & Mars Orange & Reforma Incised: Mucnal Variety & Volcanic & bowl & 1 & Southern Gulf \\
\hline HTN093 & $3 / 1 / 06$ & Mars Orange & Savana Orange: Rejolla Variety & Volcanic & jar & 1 & Various (Belize) \\
\hline HTN094 & $3 / 1 / 06$ & Mars Orange & Savana Orange: Rejolla Variety & Volcanic & jar & 1 & Various (Belize) \\
\hline HTN095 & $3 / 1 / 06$ & Mars Orange & Savana Orange: Rejolla Variety & Volcanic & bowl & 1 & Various (Belize) \\
\hline HTN096 & $3 / 1 / 06$ & Undetermined & Undetermined & Calcite & jar & 4 & Lake Peten region \\
\hline HTN097 & $3 / 1 / 06$ & Undetermined & Undetermined & Calcite & bowl & 4 & Lake Peten region \\
\hline
\end{tabular}


Table 2. Elemental Loadings for the pottery sample on Principal Component Axes 1 through 5*.

*Values in bold explain the greatest amount of variation within each component. Those in italics explain a significant portion of the variation, but less than those in bold.

\begin{tabular}{|c|c|c|c|c|c|c|}
\hline Variable & Mean & PC1 & PC2 & PC3 & PC4 & PC5 \\
\hline $\mathrm{Na}$ & 2163.7806 & 0.092 & -0.416 & -0.690 & -0.156 & -0.267 \\
\hline $\mathrm{Ca}$ & 63050.6437 & -0.417 & 0.254 & -0.089 & 0.407 & -0.605 \\
\hline Cs & 3.2848 & 0.308 & -0.265 & 0.196 & 0.314 & -0.353 \\
\hline $\mathrm{Mn}$ & 223.2515 & -0.003 & 0.195 & -0.523 & 0.118 & 0.138 \\
\hline $\mathrm{Cr}$ & 67.3654 & 0.059 & 0.138 & 0.087 & -0.092 & -0.279 \\
\hline As & 6.2480 & 0.176 & 0.071 & 0.186 & -0.250 & 0.029 \\
\hline K & 5912.5828 & 0.258 & -0.371 & -0.048 & 0.252 & 0.226 \\
\hline $\mathrm{Rb}$ & 50.1245 & 0.296 & -0.325 & 0.115 & 0.320 & -0.161 \\
\hline $\mathrm{Ba}$ & 501.1936 & 0.081 & -0.008 & -0.153 & -0.166 & -0.197 \\
\hline Co & 6.6629 & 0.080 & 0.224 & -0.201 & 0.055 & 0.061 \\
\hline Ta & 0.9569 & 0.179 & 0.047 & 0.108 & -0.119 & -0.178 \\
\hline $\mathrm{Ti}$ & 3521.7425 & 0.129 & 0.089 & 0.064 & -0.126 & -0.206 \\
\hline $\mathrm{Nd}$ & 18.6108 & 0.211 & 0.198 & -0.062 & 0.210 & 0.069 \\
\hline La & 20.6523 & 0.210 & 0.152 & -0.067 & 0.191 & 0.043 \\
\hline V & 67.8096 & 0.116 & 0.070 & 0.144 & -0.040 & -0.175 \\
\hline $\mathrm{Tb}$ & 0.5465 & 0.206 & 0.208 & -0.033 & 0.112 & 0.047 \\
\hline$U$ & 2.0180 & 0.148 & 0.014 & -0.070 & -0.112 & 0.045 \\
\hline $\mathrm{Hf}$ & 5.7976 & 0.103 & 0.073 & -0.039 & -0.202 & -0.158 \\
\hline $\mathrm{Sm}$ & 4.1557 & 0.205 & 0.199 & -0.056 & 0.160 & 0.058 \\
\hline $\mathrm{Ce}$ & 53.6780 & 0.198 & 0.229 & -0.099 & 0.089 & 0.012 \\
\hline $\mathrm{Eu}$ & 0.7653 & 0.185 & 0.215 & -0.069 & 0.163 & 0.039 \\
\hline $\mathrm{Sb}$ & 1.0048 & 0.113 & -0.007 & -0.028 & -0.142 & -0.045 \\
\hline Th & 11.1042 & 0.134 & 0.033 & 0.004 & -0.210 & -0.115 \\
\hline $\mathrm{Zn}$ & 64.1681 & 0.106 & 0.013 & 0.000 & -0.097 & -0.052 \\
\hline Dy & 3.4941 & 0.192 & 0.156 & -0.010 & 0.077 & 0.018 \\
\hline $\mathrm{Yb}$ & 2.3318 & 0.175 & 0.145 & -0.026 & -0.039 & -0.026 \\
\hline Lu & 0.3389 & 0.169 & 0.104 & -0.031 & -0.049 & 0.008 \\
\hline $\mathrm{Zr}$ & 138.9978 & 0.103 & 0.086 & -0.051 & -0.130 & -0.097 \\
\hline Sc & 11.6184 & 0.102 & 0.030 & 0.037 & -0.160 & -0.161 \\
\hline $\mathrm{Fe}$ & 30690.4932 & 0.121 & 0.072 & 0.027 & -0.181 & -0.106 \\
\hline $\mathrm{Al}$ & 77919.1412 & 0.085 & 0.024 & -0.071 & -0.184 & -0.098 \\
\hline Eigenvalues: & & 1.536 & 0.292 & 0.165 & 0.091 & 0.052 \\
\hline total variation & explained: & 66.334 & 12.627 & 7.104 & 3.911 & 2.246 \\
\hline
\end{tabular}

